Journal for ImmunoTherapy of Cancer

\title{
ALKS 4230: a novel engineered IL-2 fusion protein with an improved cellular selectivity profile for cancer immunotherapy
}

\author{
Jared E Lopes, ${ }^{1}$ Jan L Fisher, ${ }^{2}$ Heather L Flick, ${ }^{1}$ Chunhua Wang, ${ }^{1}$ Lei Sun, \\ Marc S Ernstoff, ${ }^{3}$ Juan C Alvarez, ${ }^{4}$ Heather C Losey ${ }^{1}$
}

To cite: Lopes JE, Fisher JL, Flick HL, et al. ALKS 4230: a novel engineered IL-2 fusion protein with an improved cellular selectivity profile for cancer immunotherapy. Journal for ImmunoTherapy of Cancer 2020;8:e000673. doi:10.1136/ jitc-2020-000673

- Additional material is published online only. To view please visit the journal online (http://dx.doi.org/10.1136/jitc2020-000673).

Accepted 24 March 2020

Check for updates

(c) Author(s) (or their employer(s)) 2020. Re-use permitted under CC BY-NC. No commercial re-use. See rights and permissions. Published by BMJ.

${ }^{1}$ Research, Alkermes, Inc, Waltham, Massachusetts, USA ${ }^{2}$ Department of Medicine, The Geisel School of Medicine at Dartmouth and Norris Cotton Cancer Center, Lebanon, New Hampshire, USA

${ }^{3}$ Department of Medicine, Roswell Park Cancer Institute, Buffalo, New York, USA

${ }^{4}$ Computational and Structural Chemistry, Merck \& Co, Boston, Massachusetts, USA

Correspondence to Dr Heather C Losey; Heather.Losey@alkermes.com

\section{ABSTRACT}

Background Interleukin-2 (IL-2) plays a pivotal role in immune homeostasis due to its ability to stimulate numerous lymphocyte subsets including natural killer (NK) cells, effector $\mathrm{CD}^{+}$and $\mathrm{CD} 8^{+} \mathrm{T}$ cells, and regulatory $\mathrm{T}$ cells $\left(T_{\text {regs }}\right)$. Low concentrations of IL-2 induce signaling through the high-affinity IL-2 receptor (IL-2R) comprised of IL-2R $\alpha$, IL-2R $\beta$, and common $\gamma$ chain $\left(\gamma_{c}\right)$, preferentially expressed on $\mathrm{T}_{\text {regs }}$. Higher concentrations of IL-2 are necessary to induce signaling through the intermediateaffinity IL-2R, composed of IL-2R 3 and $\gamma$, expressed on memory $\mathrm{CD}^{+} \mathrm{T}$ cells and NK cells. Recombinant human IL-2 (rhlL-2) is approved for treatment of metastatic melanoma and renal cell carcinoma (RCC), but adverse events including capillary leak syndrome, potentially mediated through interaction with the high-affinity IL-2R, limit its therapeutic use. Furthermore, antitumor efficacy of IL-2 may also be limited by preferential expansion of immunosuppressive $T_{\text {regs }}$. ALKS 4230 is an engineered fusion protein comprised of a circularly-permuted IL-2 with the extracellular domain of IL-2R $\alpha$, designed to selectively activate effector lymphocytes bearing the intermediateaffinity IL-2R.

Results ALKS 4230 was equipotent to rhlL-2 in activating human cells bearing the intermediate-affinity IL-2R, and less potent than rhlL-2 on cells bearing the high-affinity $\mathrm{IL}-2 \mathrm{R}$. As observed in vitro with primary human cells from healthy donors and advanced cancer patients, ALKS 4230 induced greater activation and expansion of NK cells with reduced expansion of $\mathrm{T}_{\text {regs }}$ relative to rhlL2. Similarly, in mice, ALKS 4230 treatment stimulated greater expansion of NK cells and memory-phenotype $\mathrm{CD}^{+} \mathrm{T}$ cells at doses that did not expand or activate $\mathrm{T}_{\text {regs. }}$. ALKS 4230 treatment induced significantly lower levels of proinflammatory cytokines, including tumor necrosis factor alpha, interleukin-6, and interferon gamma relative to rhIL2. Furthermore, ALKS 4230 exhibited superior antitumor efficacy in the mouse B16F10 lung tumor model, where ALKS 4230 could be administered via multiple routes of administration and dosing schedules while achieving equivalent antitumor efficacy.

Conclusions ALKS 4230 exhibited enhanced pharmacokinetic and selective pharmacodynamic properties resulting in both improved antitumor efficacy and lower indices of toxicity relative to rhlL-2 in mice. These data highlight the potential of ALKS 4230 as a novel cancer immunotherapy, and as such, the molecule is being evaluated clinically.

\section{BACKGROUND}

Recombinant human interleukin-2 (rhIL-2, aldesleukin) is approved for the treatment of metastatic melanoma and renal cell carcinoma (RCC).${ }^{1-8}$ However, the use of rhIL-2 is limited to patients with normal cardiac and pulmonary function due to associated capillary leak syndrome and resulting fluid shifts, hypovolemia, and hypotension associated with end-organ dysfunction. ${ }^{9-12}$ Despite the poor tolerability of immunotherapy with rhIL-2, it remains one of the few treatment regimens for metastatic melanoma and RCC that elicits a complete and durable response in a subset of patients, up to $12 \%$ in melanoma and $7 \%$ in RCC. ${ }^{78}$

IL-2 plays a pivotal role in the regulation of immune responses due to its ability to stimulate numerous lymphocyte subsets with distinct cellular functions such as natural killer (NK) cells, B cells, and effector T cells in addition to regulatory $\mathrm{T}$ cells $\left.\left(\mathrm{T}_{\text {regs }}\right)\right)^{13-15}$ It has been postulated that a contributing factor limiting the therapeutic efficacy of rhIL-2 is that it preferentially activates and induces the expansion of immunosuppressive $\mathrm{CD} 4{ }^{+} \mathrm{T}_{\text {regs }}{ }^{16}{ }^{16}$ which can counteract antitumor immune responses. ${ }^{17} 18$ In support of this hypothesis, the expansion of inducible $\mathrm{T}$ cell costimulator-positive $\left(\mathrm{ICOS}^{+}\right) \mathrm{T}_{\text {regs }}$ in a subset of melanoma patients receiving high-dose IL-2 therapy correlated with poor outcome. ${ }^{19}$ The preferential activation of lymphocytes with regulatory functions over those with host-protective functions is explained by IL-2 receptor pharmacology. Low concentrations (pM range) of IL-2 signal through the highaffinity IL-2 receptor (IL-2R) comprised of IL-2R $\alpha$ (CD25), IL-2R $\beta$ (CD122), and 
common $\gamma$ chain $\left(\gamma_{c}\right.$, CD132). IL-2R $\alpha$ is inducibly expressed on activation of effector T cells and NK cells but constitutively expressed on $\mathrm{T}_{\text {regg }}{ }^{20}$ Higher concentrations (nM range) of IL-2 are necessary to induce signaling through the intermediate-affinity $\mathrm{IL}-2 \mathrm{R},{ }^{15}$ composed of IL-2R $\beta$ and $\gamma_{c}$, constitutively expressed on memory $\mathrm{CD}^{+} \mathrm{T}$ cells and NK cells, which have been shown to be required for protective anticancer immune responses. ${ }^{21}$

A second limitation of high-dose rhIL-2 treatment is the risk of capillary leak syndrome. ${ }^{22}$ In preclinical studies, administration of IL-2 induced pulmonary edema, observed as increases in wet pulmonary weight, in wild-type mice and in mice where expression of the high-affinity IL-2R is restricted to non-hematopoietic cells. ${ }^{23}$ In these studies, treatment with rhIL-2 resulted in upregulation of IL-2R $\alpha$ on lung endothelial cells, and blocking the IL-2R $\alpha$ binding interface on IL-2 with a monoclonal antibody allowed for significant activation of intermediate-affinity IL-2R-expressing cells without increasing wet pulmonary weight. These data support the hypothesis that direct interaction between IL-2 and highaffinity IL-2R on pulmonary endothelial cells contributes to increased vascular permeability.

Several strategies have been published with the specific goals of improving antitumor efficacy and treatment tolerability by selectively stimulating the intermediateaffinity IL-2 $\mathrm{R}^{23-27}$ to preferentially drive the activation and expansion of NK cells, effector, and memory $\mathrm{CD} 8^{+}$ T cells. ${ }^{24}{ }^{25}$ Described herein is the design and immunological characterization of ALKS 4230, a fusion protein of circularly permuted IL-2 to the extracellular domain of IL-2R $\alpha$, designed to interact with the intermediateaffinity IL-2R and not the high-affinity IL-2R to selectively activate effector lymphocytes.

\section{METHODS}

All mice used in these studies were housed, managed, and cared for in accordance with the Guide for the Care and Use of Laboratory Animals (National Research Council, 2011).

\section{In vitro immune cell stimulation}

To assess activity on murine lymphocyte populations, pooled splenocytes were isolated from C57BL/6 mice. To assess activity on human lymphocyte populations, leukocytes were isolated from human whole blood using a standard red blood cell lysis procedure. Mouse splenocytes, human HH (ATCC) and NK-92 (ATCC) cell lines, and human lymphocytes were then stimulated with ALKS 4230 or rhIL-2 and stained with fluorescently-conjugated antibodies against $\mathrm{CD}^{+} \mathrm{T}_{\text {reg }}$, NK cell, or memory $\mathrm{CD}^{+} \mathrm{T}$ cell surface markers (Additional File 2: mouse splenocyte markers in online supplementary table S1 and human lymphocyte markers online supplementary table S2), and the intracellular proteins, FoxP3 and pSTAT5 (pY694), as applicable. Cells were acquired on a BD LSR Fortessa X-20 and analyzed using FlowJo software (v.X.0.7). Additional details can be found in the online supplementary methods section.

\section{Analysis of human peripheral blood mononuclear cells}

Peripheral blood mononuclear cells (PBMCs) were isolated, expanded, and stimulated according to protocols approved by the Dartmouth Committee for the Protection of Human Subjects. PBMC samples were resuspended and cultured with anti-CD3 antibody and either 0.5 nM ALKS 4230 or $0.5 \mathrm{nM}$ rhIL-2. On Day 5, 7, and 9 cells were harvested, washed, and resuspended with fresh $0.5 \mathrm{nM}$ ALKS 4230 or rhIL-2, but in the absence of anti-CD3. Cells were collected on Day 12, prepared for flow cytometry, and stained with fluorescently-conjugated antibodies (Additional File 2: online supplementary table S3) for surface and intracellular markers. Flow cytometric sample acquisition was performed on a MACSQuant 10, and cell populations were identified and quantified using FlowJo software (v.X.0.7).

\section{Mouse pharmacokinetics and pharmacodynamics}

Blood samples for pharmacokinetic assessments were obtained from female C57BL/6 mice at various timepoints after a single intravenous (IV) or subcutaneous (SC) administration of ALKS 4230 (3 $\mu \mathrm{g}$ IV or $8 \mu \mathrm{g} \mathrm{SC}$ ) ( $\mathrm{n}=6$ per group) or SC administration of rhIL-2 (20 or $50 \mu \mathrm{g})$ ( $\mathrm{n}=12$ per group). Serum concentrations of ALKS 4230 or IL-2 were quantified using a human IL-2 electrochemiluminescence assay kit (Meso Scale Discovery). Pharmacokinetic parameters were calculated by a standard non-compartmental analysis method using Phoenix WinNonlin V.6.4 (Pharsight, A Certara Company).

To determine pharmacodynamic responses in normal mice, five groups of female C57BL/ 6 mice ( $\mathrm{n}=9$ per group) received SC injections once daily with vehicle (phosphatebuffered saline (PBS) ), 20 or $50 \mu \mathrm{g}$ rhIL-2 in PBS and 8 or 12 $\mu \mathrm{g}$ ALKS 4230 in PBS. On the morning of the $6^{\text {th }}$ day, mice were euthanized. The spleens and lungs were removed, and the weight of each tissue was recorded. The lung tissue samples were then dehydrated by incubation at $60^{\circ} \mathrm{C}$ for 48 to 72 hours. The resulting dry lung weight was recorded and the weight due to pulmonary fluid (wet lung weight) was calculated. After harvest, spleens from each animal were homogenized followed by red blood cell lysis to isolate splenocytes. Splenocytes were stained using fluorescentlylabeled antibodies against markers indicative of $\mathrm{CD}^{+} \mathrm{T}_{\text {regs }}$, NK cells, $\mathrm{CD}^{+} \mathrm{T}$ cells, and memory-phenotype $\mathrm{CD} 8^{+} \mathrm{T}$ cells (Additional File 2: online supplementary table S4). Samples were acquired and analyzed on a BD LSR Fortessa X-20 and quantified by FlowJo software (v.X.0.7).

To compare the production of serum cytokines in response to treatment, female $\mathrm{C} 57 \mathrm{BL} / 6$ mice were treated SC daily for 4 days with 20,50 , or $75 \mu \mathrm{g}$ rhIL-2 and 8, 20, or $30 \mu \mathrm{g}$ ALKS 4230. Blood samples were harvested from $\sim \mathrm{N}=5$ mice per time point at 2, 4, 6, and 24 hours post-dose on Day 1 and Day 4. Serum cytokines were quantified using the V-PLEX Proinflammatory Panel 1 Mouse electrochemiluminescence assay kit (Meso Scale Discovery). 


\section{B16F10 lung tumor colonization model}

On Day $1,1.5 \times 10^{5}$ B16F10 mouse melanoma cells were injected IV into female B6D2F1 mice ( $\mathrm{n}=10$ /group), followed by initiation of treatment on Day 2. The studies were terminated on approximately Day 10 to 12 , once the number of tumor colonies in a separate cohort of animals had reached 50 to 120 tumor colonies per lung. Lungs were collected, and the numbers of colonies were counted with a stereo microscope.

\section{Statistical analysis}

GraphPad Prism 8.0 was used for statistical analyses and graphical representations. Relevant statistical tests were performed as indicated for each experiment in the figure legends.

\section{RESULTS}

\section{Design and structure of circularly permuted IL-2 fused to IL- 2Ro}

We hypothesized that a covalent fusion of IL-2 with IL-2R $\alpha$ would lose the ability to signal through the highaffinity IL-2R, sterically inhibiting interaction with endogenous IL-2R $\alpha$, but retain the ability to signal through the

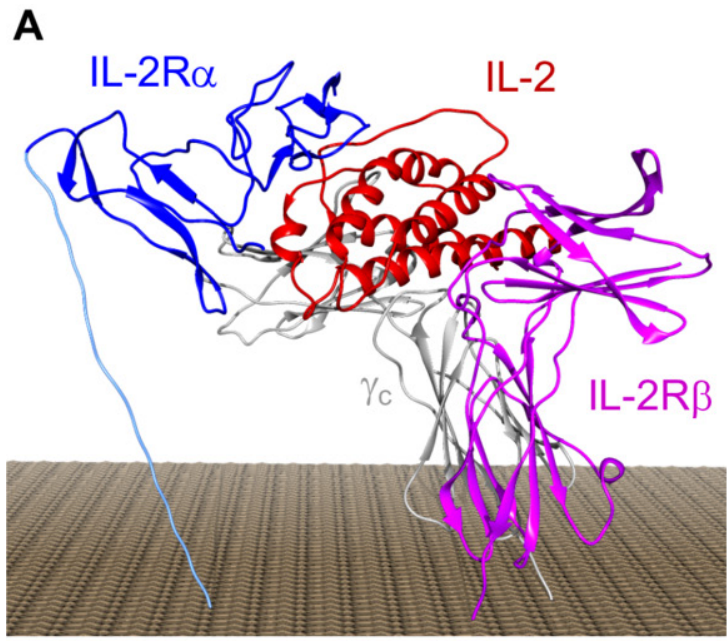

D

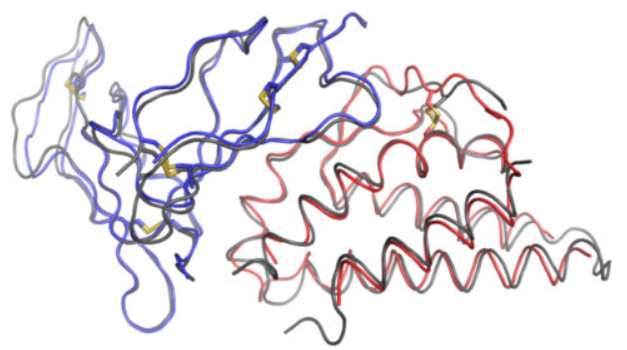

intermediate-affinity IL-2R. This fusion protein would shift the balance towards selective activation of effector lymphocytes over $\mathrm{T}_{\text {regs }}$ relative to rhIL-2. The crystal structure of the quaternary complex of human IL-2 bound to the high-affinity IL-2R ${ }^{28}$ (figure 1A), comprised of IL-2R $\alpha$, IL-2R $\beta$, and $\gamma$, was used to guide the design of the IL-2:IL-2R $\alpha$ fusion molecule. In that structure, the closest spatial distance between the fusible termini of IL-2 and IL-2R $\alpha$ is from the C-terminus of IL-2 to the N-terminus of IL-2R $\alpha$ at a distance of $50 \AA$, requiring a linker of at least 20 amino acids. The position of the required linker may also impede the interaction of IL-2 with its $\beta$ and $\gamma$ chains, as was observed previously for fusions of IL-2 with IL-2R $\alpha$ constructed via the native termini, resulting in significantly diminished bioactivity. ${ }^{29}$ To circumvent these issues, circular permutation of recombinant human IL-2 was employed, utilizing the sequence derived from the rhIL-2 therapeutic, aldesleukin, which bears a Cys125Ser substitution (Additional File 2: online supplementary table S5). Circular permutation is a protein engineering tool that involves joining of the native amino and carboxy ends of a protein with an amino acid linker and creating new amino and carboxy termini at a new

B

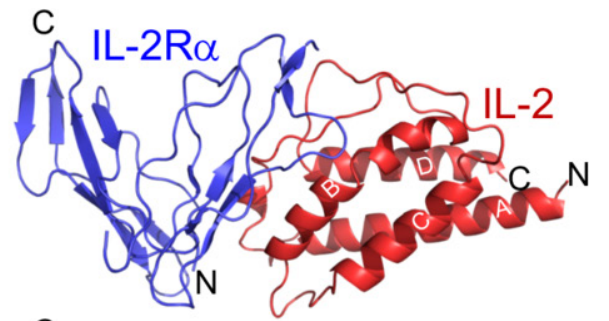

C

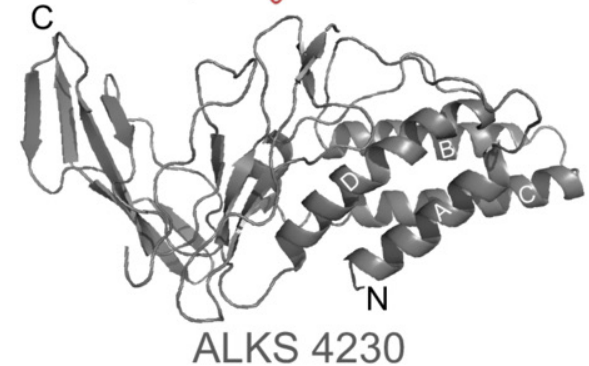

$\mathbf{E}$

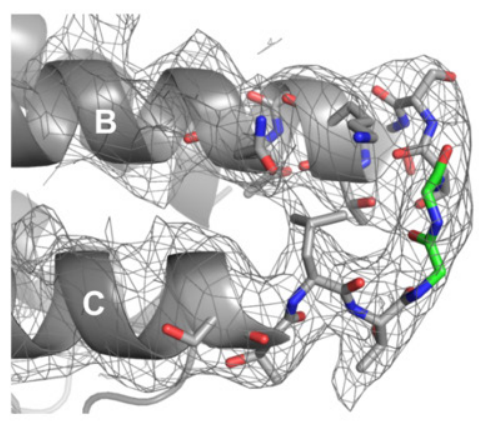

Figure 1 ALKS 4230 is a novel engineered fusion protein between circularly permuted IL-2 and IL-2R $\alpha$. (A) Published crystal structure of the quarternary complex of human IL-2 bound to the high-affinity IL-2 receptor (PDB ID 2B5I). (B) Visualization of spatial distance between unfused IL-2 and IL-2R $\alpha$ (helices identified by white lettering A to D, with native N-termini and Ctermini labeled). (C) Modeled structure of ALKS 4230 with new N-termini and C-termini labeled. (D) Structural overlay of ALKS 4230 (in gray) with PDB ID 1 Z92 (in red and blue). (E) Observation of electron density between C-terminal Thr133 and N-terminal Ser26 of IL-2. IL-2,interleukin-2; IL-2R, IL-2 receptor. 
site within the protein sequence. The primary sequence of the resulting protein is reordered, while the secondary structure and activity are retained. In the case of IL-2, a $\mathrm{Gly}_{2}$ linker was used in addition to disordered residues Ser4 and Ser5 (numbering derived from Uniprot P60568 without the signal sequence; Additional File 2: online supplementary table S5) to traverse the $12.9 \AA$ distance between the C-terminal Thr133 and N-terminal Ser6 of IL-2, thus creating a covalent linkage between the D and A helices of IL-2 (figure 1B). To complete the circular permutation, a chain break was introduced in the loop between the $\mathrm{B}$ and $\mathrm{C}$ helices of IL-2, creating new N-termini and C-termini of IL-2 (Ser75 and Gln74, respectively) at a site proximal to the N-terminal Glu1 of IL-2R $\alpha$ (numbering derived from Uniprot P01589 without the signal sequence; Additional File 2: online supplementary table S5), resulting in circularly permuted IL-2 (cpIL-2). With the newly formed termini in cpIL-2, the distance between the C-terminal Gln74 of cpIL-2 from the N-terminal Glu1 of IL-2R $\alpha$ is only $12.4 \AA$, enabling use of a short six residue Gly-Ser-Gly ${ }_{2}-S e r$ linker to fuse cpIL-2 to the extracellular domain of IL-2R $\alpha$ (residues 1 to 165 ; figure 1C). The corresponding gene encoding the cpIL2:IL-2R $\alpha$ amino acid sequence (Additional File 2: online supplementary table S5), hereafter referred to as ALKS 4230, was synthesized and expression was carried out in chinese hamster ovary (CHO) cells. After purification, the resulting protein was $>95$ percent pure by sodium dodecyl sulfate-polyacrylamide gel electrophoresis (SDSPAGE) and characterized as a single, monomeric peak by size exclusion chromatography, with an apparent molecular weight of $55 \mathrm{kDa}$ (Additional File 3: online supplementary figure S1A-B).

To further confirm the design, the fusion protein was crystallized and the $3.4 \AA$ X-ray crystal structure solved by molecular replacement using the published structure of the IL-2:IL-2R $\alpha$ complex (1Z92; details on crystallization and refinement of ALKS 4230 in Additional File 2: online supplementary table S6 and in Additional File 1: online supplementary methods). ${ }^{28}$ The backbone of ALKS 4230 showed a $0.88 \AA$ root-mean-square deviation when overlayed with 1 Z92 (figure 1D). In addition, electron density was observed between the C-terminal Thr153 and N-terminal Ser26 of IL-2 in the engineered fusion protein (figure 1E and Additional File 3: online supplementary figure S1C-D). Overall, the X-ray structure confirmed that the design of ALKS 4230 fusion protein achieved the intended structure and conformation.

\section{ALKS 4230 selectively activates the intermediate-affinity IL- $2 \mathrm{R}$ in vitro}

Activation of the IL-2R complex triggers a cascade of membrane-proximal signaling events including, but not limited to, the phosphorylation of STAT5 (pSTAT5), translocation of PSTAT5 dimers to the nucleus, and the transcription of STAT5-regulated genes. ${ }^{20}{ }^{30}$ A phosphoflow cytometry assay was used to measure the activation of STAT5 by ALKS 4230 or rhIL-2 on two human cell lines identified to have differential expression of IL-2R $\alpha$ / CD25. ${ }^{31}{ }^{32}$ Stimulation with ALKS 4230 activated human $\mathrm{HH}$ cells expressing intermediate-affinity receptor with similar if not greater potency relative to rhIL-2 $(0.72 \mathrm{nM}$ vs $1.6 \mathrm{nM}$, figure 2A), with reduced potency on NK-92 cells expressing high-affinity receptor compared with rhIL-2 $(0.87 \mathrm{nM}$ vs $4.8 \mathrm{pM}$, figure $2 \mathrm{~B})$. To determine the cellular selectivity profile for ALKS 4230 on primary human cells, pSTAT5 was measured in cell populations from healthy donor human PBMCs (Additional File 2: online supplementary table S2). ALKS 4230 induced pSTAT5 in NK cells with an $\mathrm{EC}_{50}$ of $0.45 \mathrm{nM}$ while rhIL-2 induced pSTAT5 with an $\mathrm{EC}_{50}$ of $1.6 \mathrm{nM}$ (figure 2C; table 1). The similar potencies are consistent with both ALKS 4230 and rhIL-2 signaling through the intermediate-affinity IL-2R complex expressed on non-activated NK cells. The $\mathrm{EC}_{50 \mathrm{~s}}$ for ALKS 4230 and rhIL-2 were also similar for effector memory $\mathrm{CD}^{+} \mathrm{T}$ cells (figure 2D; table 1 ), and for naïve, central/transitional memory $\mathrm{CD} 8^{+} \mathrm{T}$ cells and terminal effector $\mathrm{CD}^{+} \mathrm{T}$ cells (table 1 ). In contrast, the potencies for ALKS 4230 and rhIL-2 differed greatly on $\mathrm{CD} 4^{+} \mathrm{CD} 25^{+-}$ FOXP3 $^{+} \mathrm{T}_{\text {regs }}$. The $\mathrm{EC}_{50}$ for rhIL-2 was $0.0015 \mathrm{nM}$, about 400 -fold lower than the $\mathrm{EC}_{50}$ of $0.59 \mathrm{nM}$ observed for ALKS 4230 (figure 2E; table 1). Therefore, ALKS 4230 is much less potent in inducing STAT5 activation in human $\mathrm{T}_{\text {regs }}$ than rhIL-2.

\section{ALKS 4230 induces the selective activation and expansion of effector lymphocytes isolated from human peripheral blood}

In order to determine whether differences in activation of STAT5 in effector versus regulatory immune cell populations incubated with ALKS 4230 and rhIL-2 translate to differences in human cellular responses, a cell proliferation assay was performed. PBMCs from healthy donors (HD) and from patients diagnosed with advanced melanoma (MEL) or advanced RCC were cultured in the presence of soluble anti-CD3 antibody and either ALKS 4230 or rhIL-2 for 5 days followed by an additional 7 days with the same IL-2R agonist but without anti-CD3. A 0.5 nM concentration of ALKS 4230 and rhIL-2 was selected for these studies based on the in vitro pSTAT5 potency data (figure 2). Samples from HD, MEL, or RCC grown in the presence of rhIL-2 expanded an average of 57 -fold, 55-fold, and 105-fold, while cells grown in the presence of ALKS 4230 expanded an average of 5-fold, 14-fold, and 15-fold, respectively (Additional File 3: online supplementary figure S2; phenotypic markers in Additional File 2: online supplementary table S3). The relative proportions of $\mathrm{T}_{\text {regs }}$, NK cells, and memory $\mathrm{T}$ cell populations that expanded in the presence of ALKS 4230 or rhIL-2 in vitro from each donor were compared. The proportion of $\mathrm{CD} 4^{+} \mathrm{CD} 25^{+} \mathrm{CD} 127^{\text {low } /-} \mathrm{T}_{\text {regs }}$ expanded in the presence of rhIL-2 were higher than when cultured in the presence of ALKS 4230 for every donor sample, regardless of disease status or cancer type, (figure $3 \mathrm{~A}$ ), and the difference in the averages was statistically significant (figure 3B). ICOS expression is induced on $\mathrm{CD} 4^{+} \mathrm{T}$ cells upon $\mathrm{T}$ cell receptor (TCR) activation as well as with IL-2 stimulation. ${ }^{19}$ There 
A

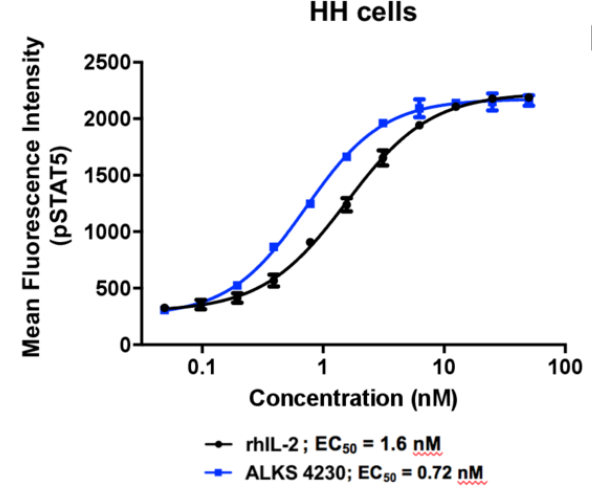

C

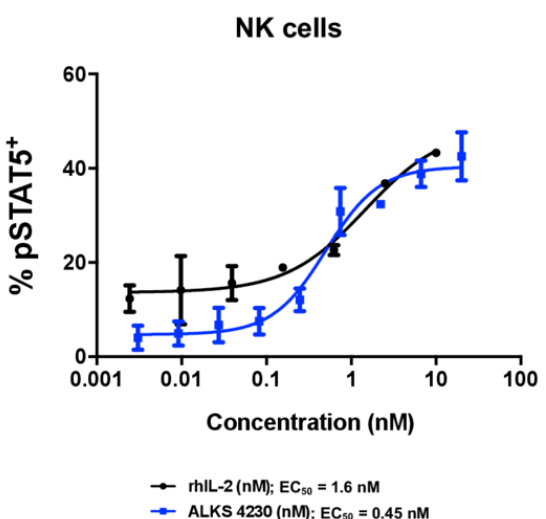

B

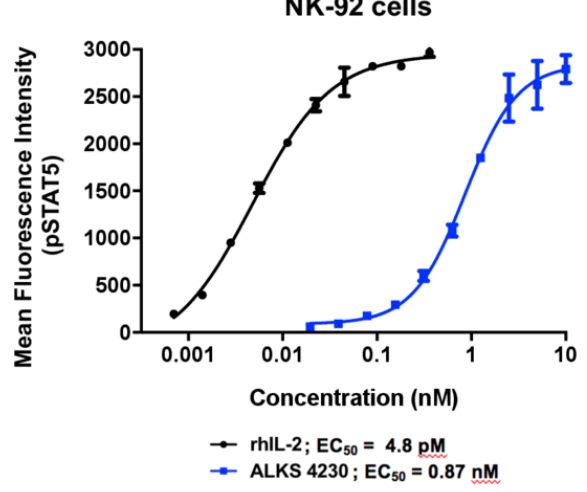

D

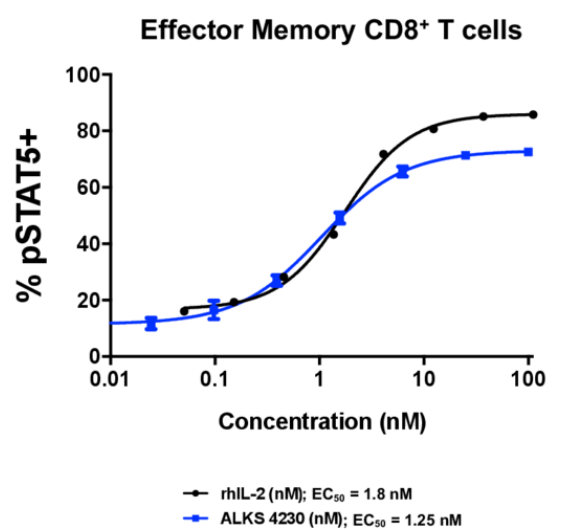

$\mathbf{E}$

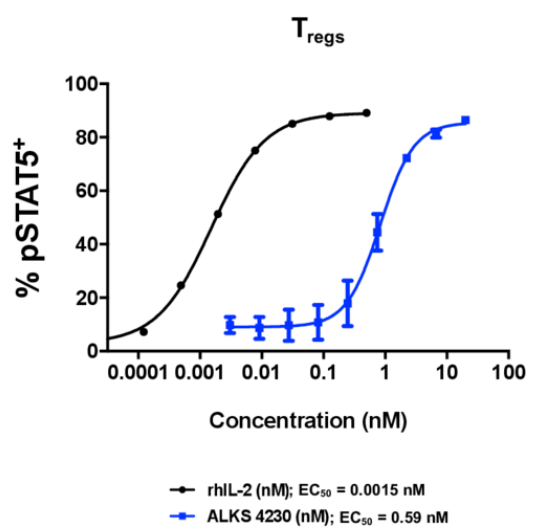

Figure 2 ALKS 4230 induced the activation of intermediate-affinity IL-2R on human cells. Cells were incubated with increasing concentrations of ALKS 4230 or rhIL-2 for 30 min and were analyzed by flow cytometry for the percent pSTAT5 ${ }^{+}$. (A) Human HH cells (lacking IL-2R $\alpha$ ) and (B) human NK-92 cells (expressing IL-2R $\alpha$ ), were treated with ALKS 4230 or rhIL-2 for 30 min and analyzed by flow cytometry. For $\mathrm{C}$ to $\mathrm{E}$, equal amounts of blood were pooled from two each of healthy male and female donors ages 19 to 48 , then leukocytes were isolated and incubated for 30 min with increasing concentrations of ALKS 4230 or rhIL-2. Cells were analyzed by flow cytometry for the percent pSTAT5 ${ }^{+}$cells in (C) NK cells, (D) effector memory CD8 ${ }^{+} \mathrm{T}$ cells, and (E) $\mathrm{T}_{\text {regs }}$. Data are representative of one experiment with each sample being stimulated in triplicate. IL-2, interleukin-2; IL-2R, IL-2

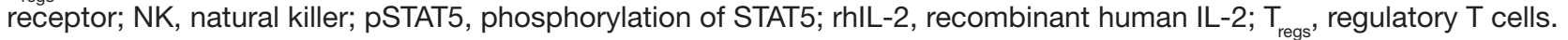

was a significantly higher percentage of $\mathrm{ICOS}^{+} \mathrm{CD}^{+} \mathrm{T}_{\text {regs }}$ when cultured with rhIL-2 $(45 \%)$ than when cultured with ALKS 4230 (25\%, figure 3C).

NK cell populations were compared and were identified based on the expression of CD56 and CD16; with
$\mathrm{CD} 56^{\text {bright }} \mathrm{CD} 16^{-}$NK cells being defined in the literature as regulatory NK cells. ${ }^{33}$ A greater proportion of $\mathrm{CD} 56^{+} \mathrm{CD} 16^{-}$ NK cells were expanded with ALKS 4230 compared with rhIL-2 for all donors (figure 3D), irrespective of disease status or cancer type, with the difference in the averages

Table 1 Potency of STAT5 activation for ALKS 4230 and rhIL-2 on selected human and mouse lymphocyte populations

\begin{tabular}{|c|c|c|c|c|}
\hline \multirow[b]{2}{*}{ Lymphocyte population } & \multicolumn{2}{|l|}{ Human } & \multicolumn{2}{|l|}{ Mouse } \\
\hline & $\begin{array}{l}\text { ALKS } 4230 \\
\mathrm{EC}_{50}(\mathrm{nM})^{*}\end{array}$ & $\begin{array}{l}\text { rhlL-2 } \\
\mathrm{EC}_{50}(\mathrm{nM}) \dagger\end{array}$ & $\begin{array}{l}\text { ALKS } 4230 \\
\mathrm{EC}_{50}(\mathrm{nM}) \dagger\end{array}$ & $\begin{array}{l}\text { rhlL-2 } \\
\mathrm{EC}_{50}(\mathrm{nM}) \dagger\end{array}$ \\
\hline NK cells & $0.45 \pm 0.09$ & 1.6 & 9.5 & 12.0 \\
\hline Memory-phenotype CD8 ${ }^{+} \mathrm{T}$ cells & & & 12.6 & 7.8 \\
\hline Naïve $\mathrm{CD} 8^{+} \mathrm{T}$ cells & $2.2 \pm 1.0$ & 1.1 & & \\
\hline Central/Transitional memory $\mathrm{CD}^{+} \mathrm{T}$ cells & $1.1 \pm 0.1$ & 2.0 & & \\
\hline Effector memory CD8 ${ }^{+} \mathrm{T}$ cells & $1.25 \pm 0.4$ & 1.8 & & \\
\hline Terminal effector $\mathrm{CD}^{+} \mathrm{T}$ cells & $0.93 \pm 0.3$ & 1.0 & & \\
\hline $\mathrm{CD}^{+} \mathrm{T}_{\text {regs }}$ & $0.59 \pm 0.2$ & 0.0015 & 12.0 & 0.011 \\
\hline
\end{tabular}

*Data was generated from three separate experiments, each performed in three replicates, and the error represents SD.

†Data was generated from one experiment performed in three replicates.

IL-2, interleukin-2; NK, natural killer; rhIL-2, recombinant human IL-2; $\mathrm{T}_{\text {regs }}$, regulatory T cells. 
A

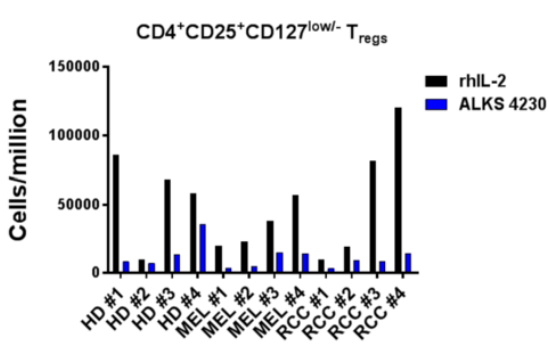

D

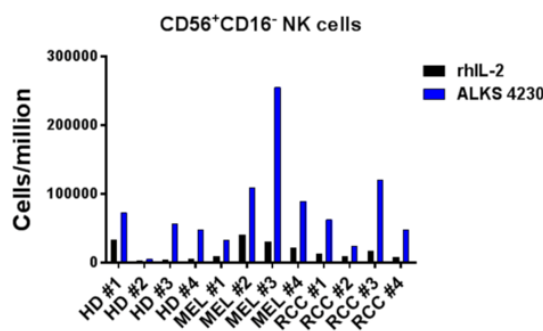

G

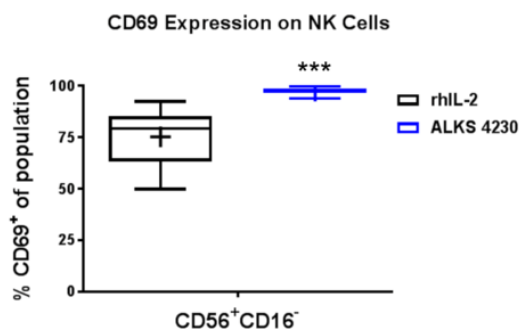

I

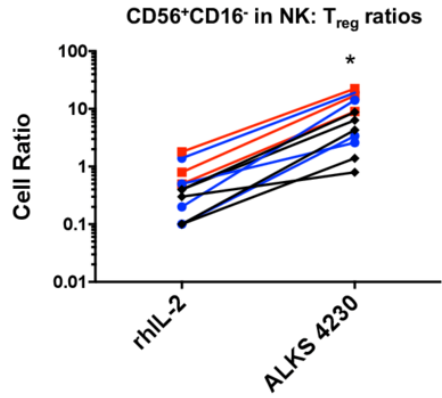

B

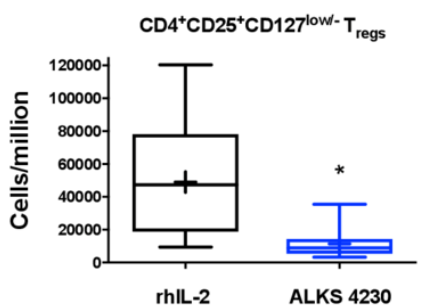

E

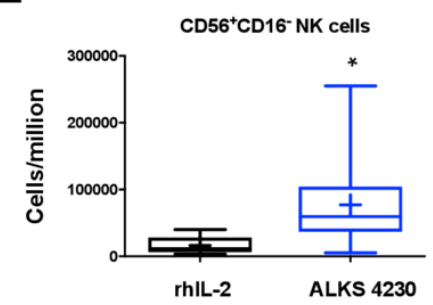

C

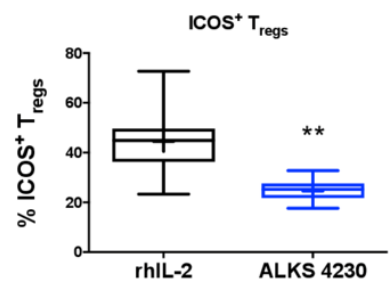

F

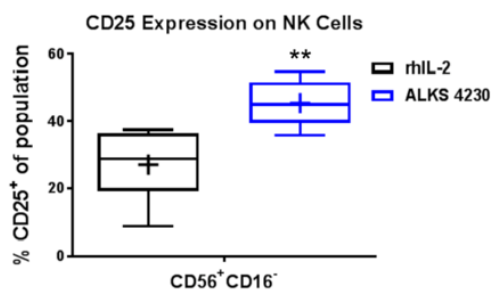

H

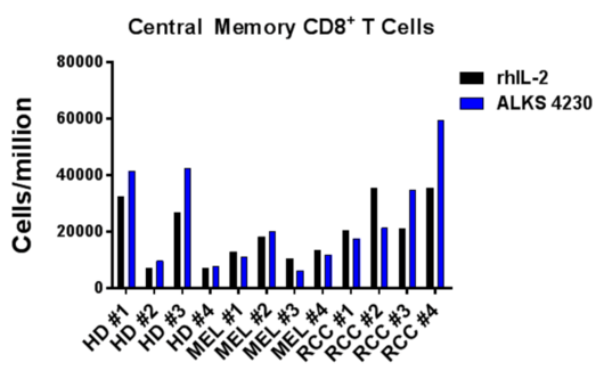

J

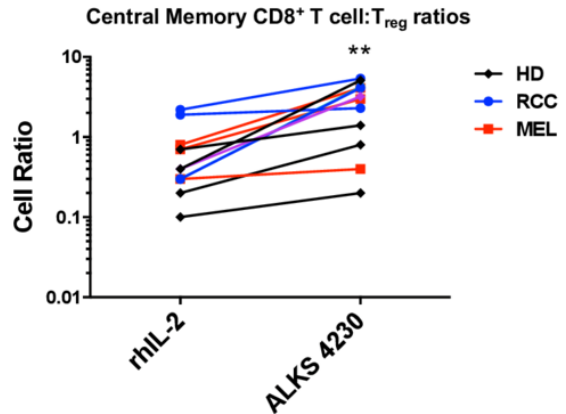

Figure 3 ALKS 4230 expanded fewer suppressive $T_{\text {regs }}$ and expanded and activated NK cells to a greater extent than rhIL-2 in human samples. Selected lymphocyte subsets identified by flow cytometry were quantified in PBMCs expanded from healthy donors (HD), individuals diagnosed with advanced melanoma (MEL), or renal cell carcinoma (RCC), with $0.5 \mathrm{nM}$ rhIL-2 or 0.5 nM ALKS 4230 ( $n=4$ for each group). Proportions of $C D 4^{+} C D 25^{+} C D 127^{\text {low/- }} T_{\text {regs }}$ from $(A)$ individual samples and the (B) average proportion by treatment. (C) Percentages of ICOS ${ }^{+} T_{\text {regs }}$ were greater in rhIL-2 expanded cultures. NK cell proportions from (D) individual samples and (E) grouped by treatment. Percentages of activated NK cells that expressed (F) CD25 and (G) CD69 were greater in ALKS 4230-expanded cultures. $(H)$ The proportion of central memory CD8 ${ }^{+}$T cells were similar in ALKS 4230 and rhIL-2-expanded cultures. The ratios of selected lymphocyte populations to $\mathrm{T}_{\text {regs }}$ were calculated in PBMCs expanded from healthy donors, and individuals diagnosed with advanced melanoma or RCC. (I) CD56 ${ }^{+} \mathrm{CD}_{16}{ }^{-} \mathrm{NK}^{-\mathrm{T}_{\text {reg }}}$ and $(\mathrm{J})$ central memory $\mathrm{CD}^{+} \mathrm{T}: \mathrm{T}_{\text {reg }}$ ratios were all significantly greater in ALKS 4230-expanded cultures. Statistical significance between treatment groups was determined by paired T tests. ${ }^{*} \mathrm{p}<0.01,{ }^{* \star} \mathrm{p}<0.001$, ${ }^{* \star *} \mathrm{p}<0.0001$. ICOS ${ }^{+}$, inducible T cell costimulator-positive; IL-2, interleukin-2; NK, natural killer; PBMCs, peripheral blood mononuclear cells; rhIL-2, recombinant human IL-2; $\mathrm{T}_{\text {regs }}$, regulatory T cells.

being statistically significant (figure 3E). The expression of CD25 and CD69, which are induced on activation and have been reported to correlate with NK cell survival and cytotoxic potential, respectively, ${ }^{1734}$ were also determined. Significantly greater percentages of $\mathrm{CD} 56^{+} \mathrm{CD} 16 \mathrm{NK}$ cells expressed CD25 and CD69 when cultured in the presence of ALKS 4230 compared with rhIL-2, with mean CD25 and $\mathrm{CD} 69^{+}$percentages of $46 \%$ and $97 \%$ compared with $27 \%$ and $75 \%$, respectively (figure $3 \mathrm{~F}-\mathrm{G}$ ). Together these data show that greater NK cell activation is achieved when culturing with ALKS 4230 than when culturing with rhIL-2 at equivalent concentrations. Finally, similar proportions 
of central memory $\mathrm{CD}^{+} \mathrm{T}$ cells resulted from culturing with ALKS 4230 and rhIL-2 (figure 3H).

As the ratios of effector cells to $\mathrm{T}_{\text {regs }}$ are considered to be a relevant biomarker of response to various cancer treatments and even prognostic of disease outcome, ${ }^{35} 36$ the ratios of NK cells and central memory $\mathrm{CD} 8^{+} \mathrm{T}$ cells to $\mathrm{T}_{\text {regs }}$ were examined. For each donor, regardless of disease status or cancer type, the ratio of $\mathrm{CD} 56^{+} \mathrm{CD} 16^{-} \mathrm{NK}$ cells to $\mathrm{T}_{\text {regs }}$ was significantly higher in response to ALKS 4230 treatment relative to treatment with rhIL-2 (figure 3I). Similarly, the ratio of central memory $\mathrm{CD} 8^{+} \mathrm{T}$ cells to $\mathrm{T}_{\text {regs }}$ was increased with ALKS 4230 treatment to a greater extent than treatment with rhIL-2 (figure 3J). No statistically significant differences were observed between the healthy, the melanoma, or the RCC donor samples within the ALKS 4230 or rhIL-2 expansion conditions.

\section{Pharmacokinetic and pharmacodynamic responses to ALKS 4230 in mice}

The pharmacokinetics of ALKS 4230 and rhIL-2 were determined after $\mathrm{SC}$ administration in $\mathrm{C} 57 \mathrm{BL} / 6$ mice (Additional File 2: online supplementary table S7). After a single SC dose of $20 \mu \mathrm{g}$ or $50 \mu \mathrm{g}$, rhIL-2 was rapidly absorbed, with peak serum concentrations $\left(\mathrm{C}_{\max }\right)$ of $38 \mathrm{nM}$ and $124 \mathrm{nM}$, respectively, observed at 15 to 30 min post-dose, followed by a rapid decrease of serum concentrations into the $\mathrm{pM}$ range within 4 to 7 hours. In contrast, after a single SC dose of $8 \mu \mathrm{g}$, the absorption of ALKS 4230 was prolonged, with a $\mathrm{C}_{\max }$ of $7.7 \mathrm{nM}$ observed 4 hours post-dose and sustained serum concentration levels in the $\mathrm{nM}$ range for at least 24 hours (figure 4A). The elimination half-life $\left(\mathrm{t}^{1 / 2}\right)$ and mean residence time (MRT) of ALKS 4230 were 4-fold to 5-fold longer and 8 -fold longer than those of rhIL-2, respectively (Additional File 2: online supplementary table $\mathrm{S} 7$ ). The relative SC bioavailability (\%F) of ALKS 4230 was $47 \%$, as determined by comparison with a single IV dose of $3 \mu \mathrm{g}$ (Additional File 2: online supplementary table S7).

In order to validate that the selectivity profile of ALKS 4230 in mice is similar to the observed profile using primary human cells, in vitro STAT5 activation was measured in immune cell populations present in spleens of naive mice (markers used to define populations shown in Additional File 2: online supplementary table S1). rhIL-2 and ALKS 4230 showed similar potency on NK cells (Additional File 3: online supplementary figure S3A and table 1) and on memory-phenotype (MP) CD8 ${ }^{+}$ $\left(\mathrm{CD}^{+} \mathrm{CD} 44^{+} \mathrm{CD} 122^{+}\right) \mathrm{T}$ cells (Additional File 3: online supplementary figure $\mathrm{S} 3 \mathrm{~B}$ and table 1 ). On $\mathrm{CD} 4^{+} \mathrm{CD} 25^{+-}$ Foxp $3^{+} \mathrm{T}_{\text {regs }}$, rhIL-2 was 1000-fold more potent than ALKS 4230 (Additional File 3: online supplementary figure S3C-D and table 1). Thus, the observed selectivity profiles were similar between mouse and human lymphocytes, supporting the use of mice to analyze pharmacodynamic responses to treatment with ALKS 4230 or rhIL-2.

The pharmacodynamic responses to ALKS 4230 and rhIL-2 were evaluated in C57BL/6 mice. The primary aim of this experiment was to compare immunological responses at dose levels selected such that pulmonary edema, a key indicator of tolerability, would be similar between rhIL-2 and ALKS 4230. Pulmonary edema resulting from capillary leak at higher doses of rhIL-2 in mice can be assessed objectively by an increase in wet pulmonary weight. ${ }^{22}{ }^{23}$ Due to the improved pharmacokinetic profile of ALKS 4230, lower doses can drive the desired pharmacodynamic responses. Thus, mice were dosed SC daily for 5 days with: vehicle, rhIL-2 at $20 \mu \mathrm{g}$ or $50 \mu \mathrm{g}$, or ALKS 4230 at $8 \mu \mathrm{g}$ or $12 \mu \mathrm{g}$. As intended, the average wet pulmonary weights from the lower dose treatment groups of ALKS 4230 and rhIL-2 were equivalent (figure 4B). Additionally, the average wet pulmonary weight from the higher dose ALKS 4230-treated group was significantly lower than the higher dose rhIL2-treated group, and similar to the lower dose ALKS 4230 and rhIL-2-treated groups (figure 4B).

Coincident with analysis of lung tissues, the spleens were harvested, and lymphocyte populations were analyzed by flow cytometry. Neither dose of ALKS 4230 resulted in increased numbers of $\mathrm{CD} 4^{+} \mathrm{CD} 25^{+} \mathrm{CD} 127^{- \text {low }} \mathrm{Foxp}^{+} \mathrm{T}_{\text {regs }}$, while treatment with rhIL-2 resulted in an average 7-fold and 5-fold expansion of $\mathrm{T}_{\text {regs }}$ relative to vehicle-treated mice (figure 4C). Increased expression of the $\mathrm{T}$ cell activation marker ICOS on $\mathrm{T}_{\text {regs }}$ in response to therapy has been correlated with poor outcome in melanoma patients treated with high-dose IL-2. ${ }^{19}$ In mice, ICOS-expressing $\mathrm{T}_{\text {regs }}$ possess superior fitness and survival, and exhibit greater suppressive function compared with $\mathrm{ICOS}^{-} \mathrm{T}_{\text {regs }}{ }^{37}$ In this study, rhIL-2 treatment increased the numbers and percentages of $\mathrm{T}_{\text {regs }}$ expressing ICOS more than ALKS 4230 (Additional File 3: online supplementary figure S4AB). Expression of two additional markers associated with $\mathrm{T}_{\text {reg }}$ suppressive function, glucocorticoid-induced TNFRrelated (GITR) protein and CD39, were analyzed, and the proportions of $\mathrm{T}_{\text {regs }}$ expressing these proteins were also increased more by rhIL-2 than ALKS 4230 (Additional File 3: online supplementary figures S4C-D). The average protein expression levels represented by geometric mean fluorescence intensity (gMFI) of ICOS, GITR, and CD39 were also dramatically increased in response to rhIL-2 but not ALKS 4230 (Additional File 3: online supplementary figures S4E-H), indicating that not only does rhIL-2 expand greater numbers of $\mathrm{T}_{\text {regs }}$, but that those $\mathrm{T}_{\text {regs }}$ may be more immunosuppressive.

Contrary to the greater expansion of $\mathrm{T}_{\text {regs }}$ by rhIL-2, ALKS 4230 preferentially expanded $\mathrm{CD}^{+} \mathrm{T}^{\mathrm{regs}}$ cell and NK cell populations. The rhIL-2 treatment induced a 7-fold to 8-fold expansion of NK cells, and a 5-fold expansion of MP $\mathrm{CD}^{+} \mathrm{T}$ cells in the 20 and $50 \mu \mathrm{g}$ rhIL-2 treatment groups, respectively (figure 4D). In contrast, treatment with ALKS 4230 induced greater expansion of NK cells (14-fold and 17-fold in the 8 and $12 \mu$ g treatment groups, respectively) and MP CD8 ${ }^{+} \mathrm{T}$ cells (15-fold and 18-fold in the 8 and $12 \mu \mathrm{g}$ treatment groups, respectively; figure 4D). Conventional $\mathrm{CD}^{+} \mathrm{T}$ cell numbers were not increased by rhIL-2, and an approximately two-fold reduction was observed in mice treated with ALKS 4230 (figure 4E). 
A

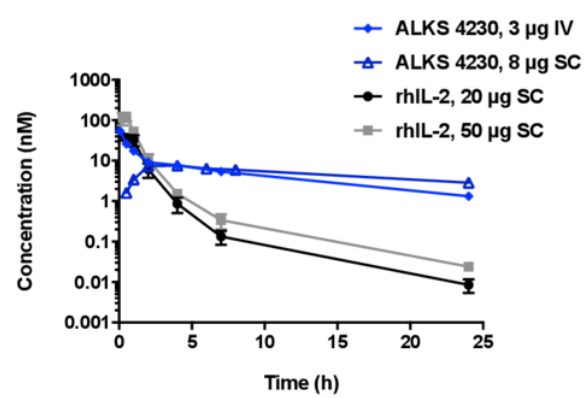

D

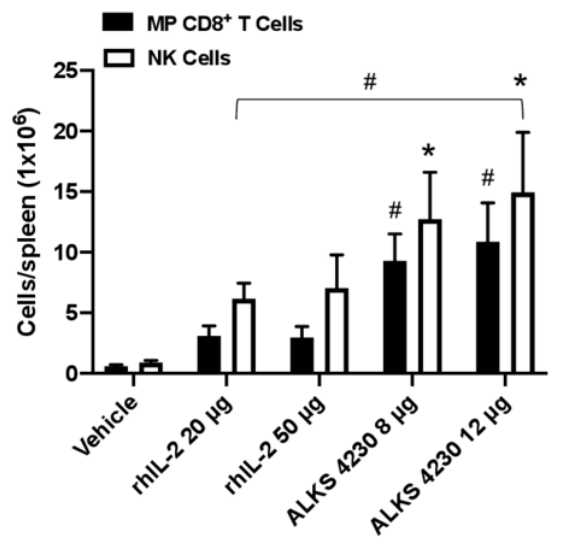

G

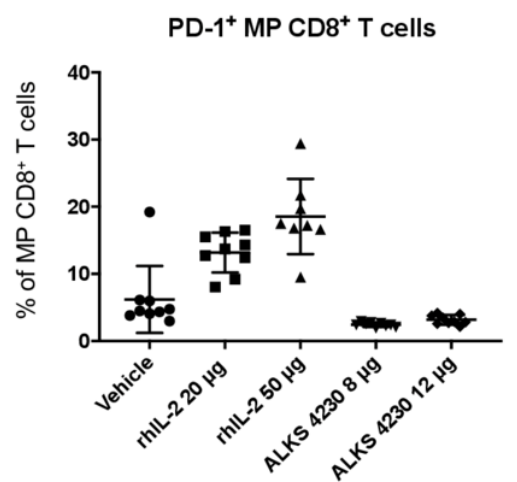

B

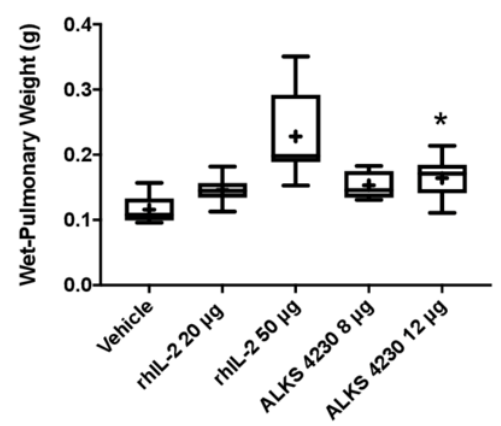

E

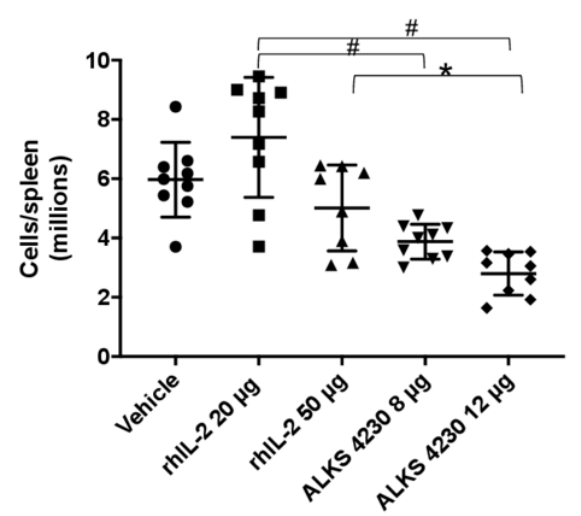

C

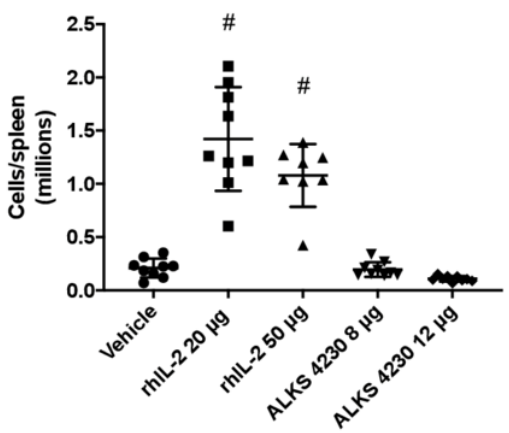

F

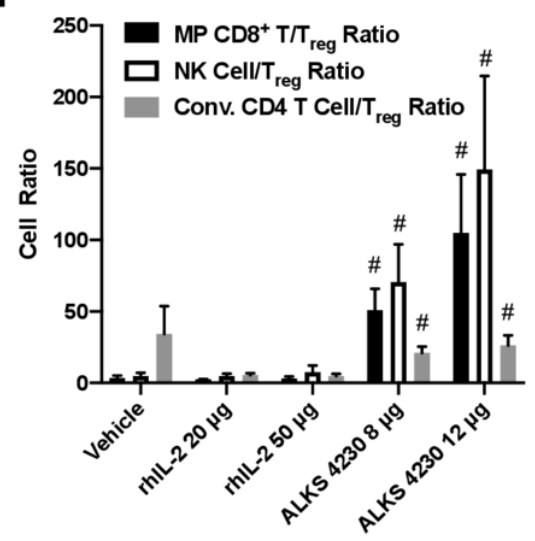

H

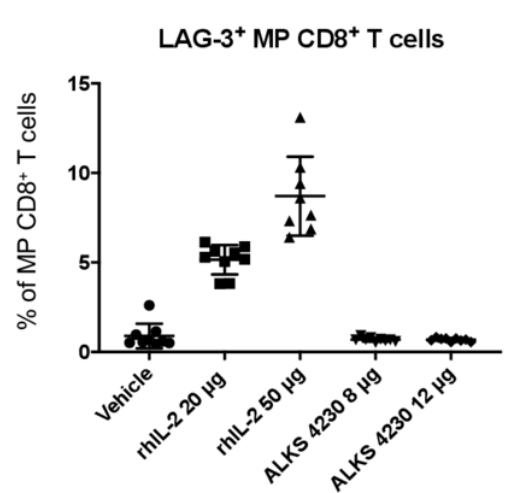

I

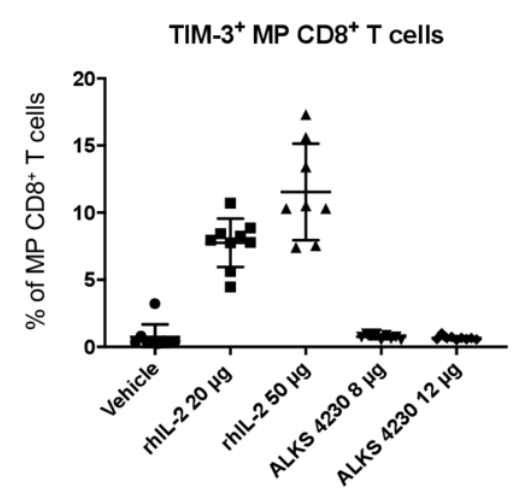

Figure 4 ALKS 4230 treatment drove selective expansion of effector cells over $\mathrm{T}_{\text {regs }}$ compared with rhIL-2 in mice. (A) Concentration-time profiles of IL-2 after a single SC dose of 20 or $50 \mu \mathrm{g}$ rhlL-2 and of ALKS 4230 after a single IV or SC dose of $3 \mu \mathrm{g}$ or $8 \mu \mathrm{g}$, respectively ( $\mathrm{n}=12$ per group). For panels $\mathrm{B}$ to $\mathrm{E}$, female C57BL/6 mice were dosed SC once a day for 5 days with the indicated doses and analyzed on Day 6. (B) Wet pulmonary weights were induced to a greater extent by rhIL-2. ${ }^{*} \mathrm{p}<0.01$ versus rhIL-2 $50 \mathrm{\mu g}$ (C) rhIL-2 induced $\mathrm{T}_{\text {reg }}$ expansion unlike ALKS 4230. \#p<0.0001 versus all. (D) ALKS 4230 expanded greater numbers of MP CD8 ${ }^{+} \mathrm{T}$ cells and NK cells relative to rhIL-2. ${ }^{*} \mathrm{p}<0.005$ versus rhlL-2 $20 \mu \mathrm{g}$, rhlL-2 $50 \mu \mathrm{g}$; \#p<0.0001 (E) ALKS 4230 treatment resulted in lower numbers of conventional $C D 4^{+} T$ cells. ${ }^{*} \mathrm{p}=0.01 ; \# p<0.0001$ (F) ALKS 4230 treatment resulted in increased ratios of NK cells, MP CD8 ${ }^{+} \mathrm{T}$ cells, and conventional $\mathrm{CD} 4^{+} \mathrm{T}$ cells to $\mathrm{T}_{\text {regs }}$, compared with rhlL-2. \#p $<0.0001$ versus rhlL-2 $20 \mu \mathrm{g}$, rhlL-2 $50 \mu \mathrm{g}$ Percentages of MP CD8 ${ }^{+}$T cells expressing (G) PD-1, (H) LAG-3, or (I) TIM-3. IL-2, interleukin-2; IV, intravenous; NK, natural killer; rhIL-2,recombinant human IL-2; SC, subcutaneous; $T_{\text {regs }}$, regulatory $T$ cells.

Reports of immune profiling of human tissues from subjects with ovarian or bladder cancer have suggested that increased ratios of the numbers of $\mathrm{CD}^{+} \mathrm{T}$ cells to $\mathrm{T}_{\text {regs }}$ are associated with improved outcomes. ${ }^{35}{ }^{36}$ A significant, dose-dependent increase in ratios of NK cells and MP CD8 ${ }^{+} \mathrm{T}$ cells to $\mathrm{T}_{\text {regs }}$ was observed in response to ALKS 4230 treatment, while no significant increase in these ratios was observed in response to treatment with rhIL-2 (figure 4F). Although ALKS 4230-treated mice exhibited $\sim 2$-fold reduction in conventional $\mathrm{CD} 4^{+} \mathrm{T}$ cells, the ratios of conventional $\mathrm{CD} 4^{+} \mathrm{T}$ cells to $\mathrm{T}_{\text {regs }}$ were higher than those observed in mice treated with either dose of rhIL-2 (figure 4F). Overall, relative to rhIL-2, treatment with ALKS 4230 resulted in significant enhancement of the ratios of NK cells and MP CD8 ${ }^{+} \mathrm{T}$ cells to $\mathrm{T}_{\text {regs }}$ at dose levels with equivalent or better tolerability. 
The expression of PD-1, LAG-3, and TIM-3 on CD8 ${ }^{+}$ $\mathrm{T}$ cells is associated with $\mathrm{T}$ cell activation, and in some contexts, functional exhaustion. ${ }^{38}{ }^{39}$ The rhIL-2 treatment significantly increased the percentage of MP $\mathrm{CD} 8^{+}$ $\mathrm{T}$ cells that expressed PD-1, LAG-3, or TIM-3 in comparison to control mice, while these cell populations were not increased by treatment with either dose of ALKS 4230 (figure 4G-I). Maturation stages of NK cells in mice have been characterized by surface expression of CD11b and CD27, with the most mature and cytolytic NK cells being described as CD11b ${ }^{+} \mathrm{CD} 27^{-40} .^{41}$ (Additional File 3: online supplementary figure S5A-B). Mice treated with either dose of ALKS 4230 had significantly higher numbers of $\mathrm{CD}_{11} \mathrm{~b}^{+} \mathrm{CD} 27^{-} \mathrm{NK}$ cells compared with mice treated with $50 \mu \mathrm{g}$ rhIL-2 (online supplementary figure S5C). Both molecules expanded comparable numbers of activated, but less mature $\mathrm{CD} 11 \mathrm{~b}^{+} \mathrm{CD} 27^{+}$NK cells (Additional File 3: online supplementary figure S5C). Additional markers associated with NK cell activation and function were evaluated. The rhIL-2 and ALKS 4230 expanded a similar proportion of NK cells that expressed KLRG1 (Additional File 3: online supplementary figure S5D), although mice treated with $50 \mu \mathrm{g}$ rhIL-2 exhibited a higher percentage of NK cells expressing NKG2D or CD69 (Additional File 3: online supplementary figure S5E-F). The increase in receptor expression levels (gMFIs) of KLRG1, NKG2D, and CD69 were consistent with the differences in the percentage of NK cells bearing these markers (Additional File 3: online supplementary figure S5G-I).
To further understand the impact of the differential pharmacodynamic effects of rhIL-2 or ALKS 4230 on key determinants of tolerability, the levels of serum proinflammatory cytokines produced in response to treatment were evaluated in a follow-up study. Mice were treated SC daily for 4 days with increasing doses of rhIL-2 or ALKS 4230 , and a time course of serum cytokine levels was evaluated post-dose on Days 1 and 4. Treatment with rhIL-2 consistently induced more significant upregulation of proinflammatory cytokines including IFN $\gamma$, TNF $\alpha$, IL-4, IL-5, IL-6, CXCL1, and IL-10 compared with ALKS 4230, which was especially apparent after the fourth day of treatment (figure 5). These data show that the selectivity of ALKS 4230 for the intermediate-affinity IL-2R translates to a greater expansion of $\mathrm{CD} 8^{+} \mathrm{T}$ cell and NK cell subsets with a more favorable systemic proinflammatory cytokine profile relative to rhIL-2 in mice. These characteristics are predicted to translate into a clinical therapy with more favorable benefit-risk attributes than rhIL-2.

\section{ALKS 4230 is efficacious in a mouse syngeneic tumor model via multiple routes of administration and dosing frequencies}

The B16F10 melanoma lung colonization model was utilized to evaluate the efficacy of rhIL-2 or ALKS 4230 after SC administration at multiple dose levels. Treatment with $20 \mu \mathrm{g}, 50 \mu \mathrm{g}$, or $75 \mu \mathrm{g}$ of rhIL-2 resulted in $61 \%, 70 \%$, and $58 \%$ inhibition of tumor growth, respectively (figure 6A). Treatment with $8 \mu \mathrm{g}, 20 \mu \mathrm{g}$, and $30 \mu \mathrm{g}$ ALKS 4230 resulted in $79 \%, 98 \%$, and $100 \%$ inhibition
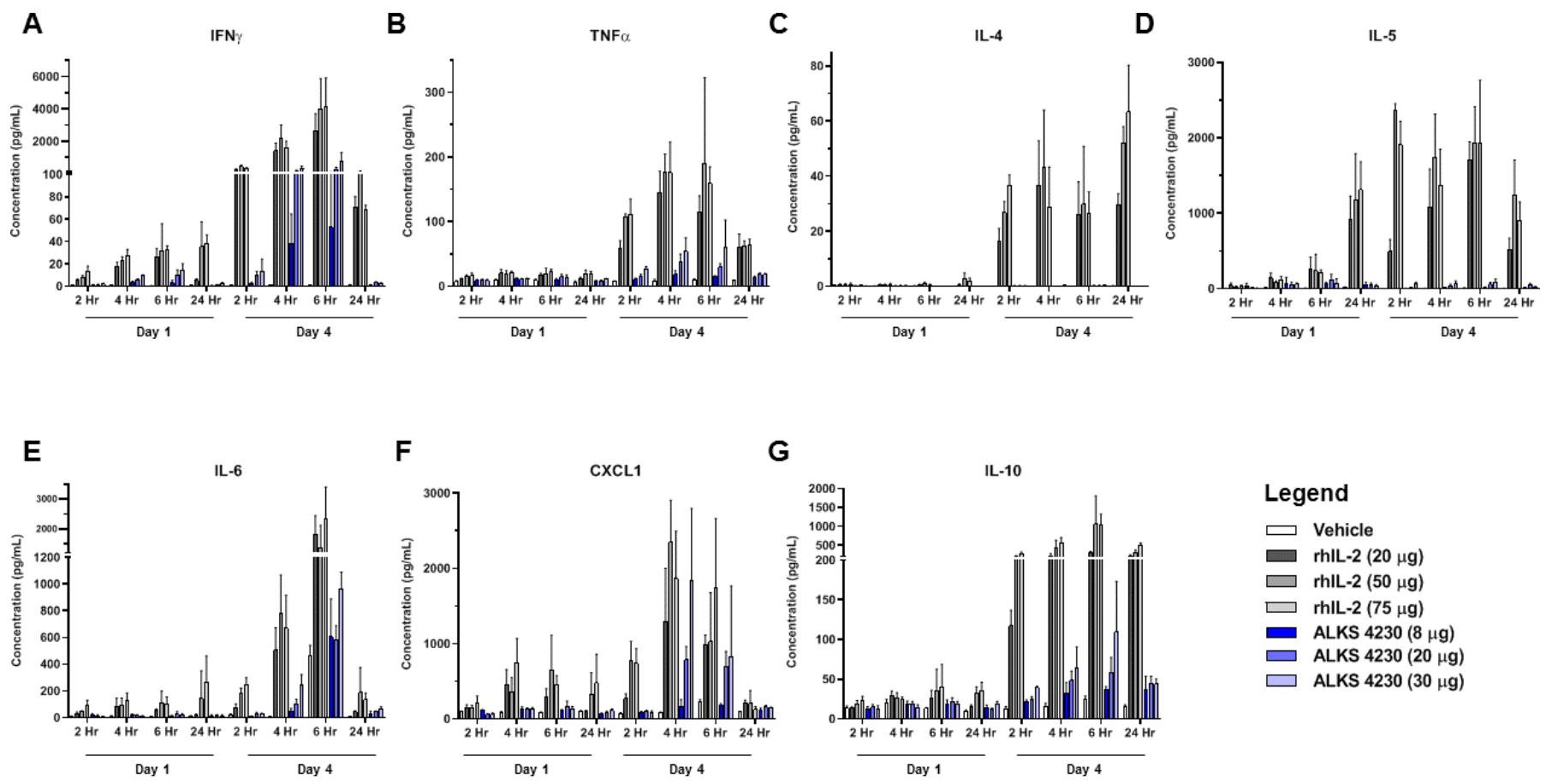

Figure 5 rhlL-2 treatment induced greater levels of systemic inflammatory cytokines in mice than ALKS 4230. Serum cytokine production was assayed in female C57BL/ 6 mice treated SC daily for 4 days with either rhIL-2 (20 $\mu \mathrm{g}, 50 \mu \mathrm{g}$, and $75 \mu \mathrm{g})$ or ALKS $4230(8 \mu \mathrm{g}, 20 \mu \mathrm{g}$, and $30 \mu \mathrm{g})$ at 2, 4, 6, and 24 hours post-dose on Day 1 and Day 4 ( $\mathrm{n}=4$ animals per time point). (A) IFN $\gamma$, (B) TNF $\alpha,(C)$ IL-4, (D) IL-5, (E) IL-6, (F) CXCL1, and (G) IL-10. IFN $\gamma$, interferon gamma; IL-2, interleukin-2; IL-6, interleukin-6; rhIL-2, recombinant human IL-2; SC, subcutaneous; TNF $\alpha$, tumor necrosis factor alpha. 


\section{Figure 6}

A

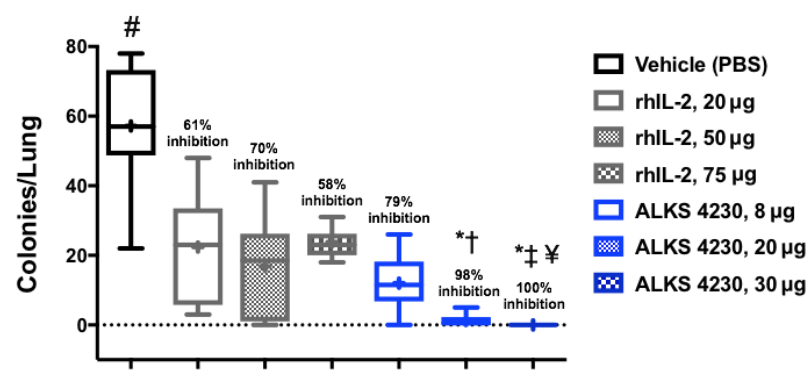

C

ALKS 4230 IV Dosing Frequency

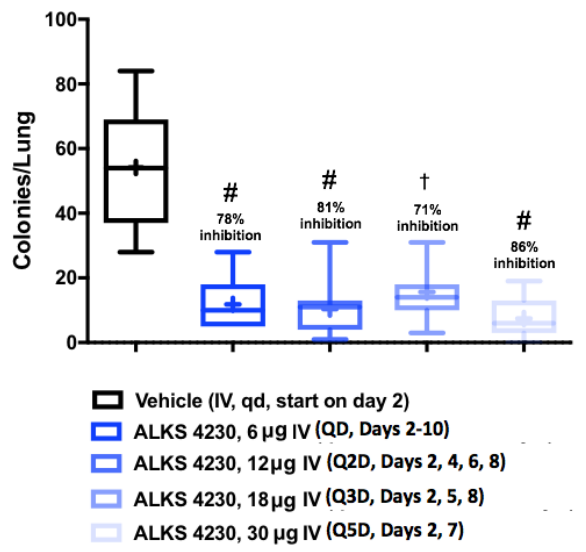

B

ALKS 4230 IV versus SC

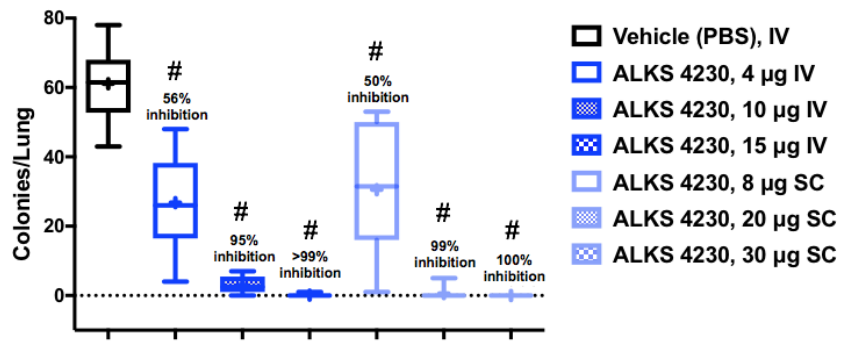

ALKS 4230 SC Dosing Frequency

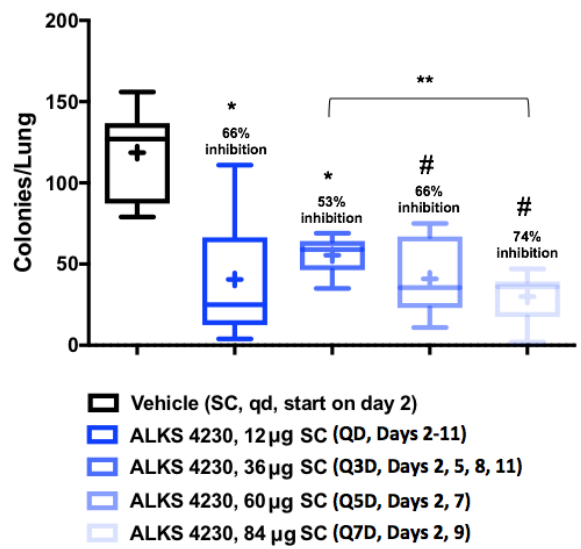

Figure 6 ALKS 4230 treatment resulted in greater inhibition of B16F10 lung tumor growth compared with rhIL-2, and could be administered IV or SC with less frequent dosing ( $n=10$ female B6D2F1 mice/group). (A) SC treatment with ALKS 4230 (8 $\mu \mathrm{g}, 20 \mu \mathrm{g}, 30 \mu \mathrm{g}$ ) resulted in complete inhibition of lung tumor growth in the murine B16F10 lung tumor colonization model. ${ }^{*} \mathrm{p}<0.05$ versus rhlL-2 $50 \mu \mathrm{g} ; \mathrm{\dagger p}<0.001$ versus rhlL-2 $20 \mu \mathrm{g}$, rhlL-2 $75 \mu \mathrm{g} ; \neq \mathrm{p}<0.001$ versus rhlL-2 $20 \mu \mathrm{g} ; ¥ \mathrm{p}<0.0001$ versus rhIL$275 \mu \mathrm{g} ; \# \mathrm{p}<0.0001$ versus all. (B) IV $(4 \mu \mathrm{g}, 10 \mu \mathrm{g}, 15 \mu \mathrm{g})$ and SC $(8 \mu \mathrm{g}, 20 \mu \mathrm{g}, 30 \mu \mathrm{g})$ ALKS 4230 inhibited tumor growth in the B16F10 lung tumor colonization model. \#p<0.001 (C) ALKS 4230 administered IV with different dosing frequencies inhibited $\mathrm{B} 16 \mathrm{~F} 10$ lung tumor growth. $\mathrm{tp}<0.0005$ versus vehicle; $\# \mathrm{p}<0.0001$ versus vehicle; (D) ALKS 4230 administered SC with different dosing frequencies inhibited B16F10 lung tumor growth. ${ }^{*} \mathrm{p}<0.001$ versus vehicle; ${ }^{* *} \mathrm{p}<0.005$; \# $\mathrm{p}<0.0001$ versus vehicle. IL-2, interleukin-2; IV, intravenous; PBS, phosphate-buffered saline; rhlL-2,recombinant human IL-2; SC, subcutaneous.

of tumor growth, respectively. Thus, rhIL-2 treatment reached a maximum of $70 \%$ tumor growth inhibition at the middle dose level with no additional benefit at a higher dose whereas ALKS 4230 treatment exhibited a clear dose response, achieving $100 \%$ inhibition of tumor growth at the highest dose level.

To better understand the relationship between route of administration and antitumor activity, additional experiments were carried out using this model. Mice were treated daily with multiple dose levels of ALKS 4230 IV (4 $\mu \mathrm{g}, 10 \mu \mathrm{g}, 15 \mu \mathrm{g})$ or SC $(8 \mu \mathrm{g}, 20 \mu \mathrm{g}, 30 \mu \mathrm{g})$. The SC dose levels were adjusted to twice those of IV to account for lower exposure, due to the $47 \%$ bioavailability previously observed for SC administration (figure 4A and Additional File 2: online supplementary table S7). Daily treatment with $4 \mu \mathrm{g}, 10 \mu \mathrm{g}$, and $15 \mu \mathrm{g}$ ALKS $4230 \mathrm{IV}$ resulted in $56 \%, 95 \%$, and greater than $99 \%$ inhibition of tumor growth, respectively (figure 6B). Similarly, treatment with $8 \mu \mathrm{g}, 20 \mu \mathrm{g}$, and $30 \mu \mathrm{g}$ ALKS $4230 \mathrm{SC}$ resulted in $50 \%, 99 \%$, and $100 \%$ inhibition of tumor growth, respectively (figure 6B). Thus, equivalent dose-dependent tumor growth inhibition was observed following IV and SC administration of ALKS 4230, with the two higher dose levels resulting in $95 \%$ to $100 \%$ inhibition of tumor growth. These data show that IV and SC administration of ALKS 4230 result in equivalent antitumor efficacy in mice, supporting that both IV and SC routes of administration merit future testing.

The effect of dosing frequency on efficacy for IV or SC administration of ALKS 4230 was investigated in order to inform selection of optimized dosing regimens for subsequent preclinical and clinical evaluation of ALKS 4230. An intermediate dose level of $6 \mu \mathrm{g}$ /day IV was chosen as a comparator for the different dosing frequencies. Three additional dose levels were chosen with the aim of matching exposure, but with less frequent dosing (12 $\mu \mathrm{g}$ 
Q2D, $18 \mu \mathrm{g}$ Q3D, and $30 \mu \mathrm{g}$ Q5D). All four dosing regimens resulted in significant inhibition of tumor growth relative to vehicle ( $71 \%$ to $86 \%$ ), with no significant differences observed between treatment groups (figure 6C).

For comparison of SC dosing regimens, a $12 \mu \mathrm{g} /$ day SC dose level was chosen to approximate the exposure of the $6 \mu \mathrm{g}$ IV daily dose evaluated in the IV study. Additional SC dose levels were chosen to match exposure with less frequent dosing as before (12 $\mu \mathrm{g}$ daily, $36 \mu \mathrm{g}$ Q3D, $60 \mu \mathrm{g}$ Q5D, and $84 \mu \mathrm{g}$ Q7D). All four dosing regimens resulted in significant inhibition of tumor growth relative to vehicle $(53 \%$ to $75 \%)$, with all groups showing similar inhibition, except for the Q7D regimen, which achieved significantly greater inhibition relative to the Q3D group (figure 6D). These data demonstrate that equivalent antitumor efficacy in this model can be achieved when ALKS 4230 is administered using a less-frequent, periodic dosing schedule via either IV or SC routes of administration, suggesting that the ALKS 4230 dosing regimen can be tailored for optimal compatibility with other agents for evaluation of combination efficacy.

\section{DISCUSSION}

High-dose IL-2 is approved and used for the treatment of metastatic melanoma and RCC, but adverse events, including capillary leak syndrome, limit its therapeutic use to a select subset of patients treated inpatient at specialized centers. Of those that are eligible and receive treatment, the overall response rates are $28 \%$ for metastatic melanoma and $23 \%$ for metastatic RCC. ${ }^{78}$ In an effort to evaluate efficacy and minimize IL-2-associated adverse effects driven by $\mathrm{C}_{\max }$, outpatient $\mathrm{SC}$ administration of lower dose IL-2 plus interferon- $\alpha$ was assessed head-tohead with the approved inpatient IV dosing regimen in metastatic RCC patients. ${ }^{8}$ Although the SC dosing regimen was better tolerated, with a higher percentage of patients completing the treatment cycle, there was a reduction in response rate (10\% vs $23 \%)$ compared with the approved IV dosing regimen. ${ }^{8}$ This may be due to the fact that lower circulating serum concentrations of IL-2, resulting from the $\mathrm{SC}$ route of administration, induce signaling through the high-affinity IL-2R. Thus, $\mathrm{T}_{\text {regs }}$ could be preferentially stimulated with this route of administration. In support of this hypothesis, low-dose IL-2 therapy is being evaluated to treat type 1 diabetes, ${ }^{42}$ lupus, ${ }^{43}$ and other autoimmune diseases, ${ }^{44}$ with the goal of activating $\mathrm{T}_{\text {regs }}$ to promote immune tolerance. Even when dosed to achieve high circulating serum concentrations to drive activation and expansion of effector cells, the antitumor efficacy of IL-2 may still be limited by its preferential expansion of immunosuppressive $\mathrm{T}_{\text {regs }}$. This is supported by the previous finding that increases in $\mathrm{ICOS}^{+} \mathrm{T}_{\text {regs }}$ in patients receiving high-dose IL-2 therapy correlate with poor outcome. ${ }^{19}$ Thus, an engineered IL-2R agonist that achieves the selective activation of the intermediateaffinity IL-2R expressed on effector cells without the need to administer high doses to overcome sequestration of
IL-2 by $\mathrm{T}_{\text {regs }} 1845$ or immunosuppression by activated $\mathrm{T}_{\text {regs }}$, has the potential to drive efficacious immune responses against tumors.

This body of work describes the design of ALKS 4230 and its potential as a novel immunotherapeutic agent that selectively activates the intermediate-affinity IL-2R. It has been reported that the three subunits of the highaffinity IL-2R, IL-2R $\alpha$, IL-2R $\beta$, and $\gamma_{c}$ are pre-associated on the cell surface. ${ }^{46}$ Whether the receptor complex is pre-associated or not, the selectivity achieved by ALKS 4230 is due to the fact that the molecule, a fusion protein of circularly permuted IL-2 to the extracellular portion of IL-2R $\alpha$, is sterically prevented from binding to IL-2R $\alpha$ of the high-affinity complex. Binding to the intermediateaffinity IL-2R complex is not impeded and may even occur on cells expressing the high-affinity IL-2R. This is supported by the finding that the in vitro potency of ALKS 4230 is similar between effector cells and $T_{\text {regs }}$ from either mouse or human origin, suggesting that ALKS 4230 is signaling through intermediate-affinity receptor complexes present on the surface of $\mathrm{T}_{\text {regs }}$. Despite the potential for STAT5 phosphorylation in $\mathrm{T}_{\text {regs }}$, no expansion of $\mathrm{T}_{\text {regs }}$ is observed and only modest increases in ICOS, GITR, or CD39 expression are observed even after repeated doses of ALKS 4230 in mice at dose levels that significantly expand NK cells and MP CD8 ${ }^{+} \mathrm{T}$ cells.

Increased ratios of $\mathrm{CD}^{+} \mathrm{T}$ cells to $\mathrm{T}_{\text {regs }}$ correlated with better response to treatment in patients with urothelial carcinoma, ${ }^{32}$ and decreased baseline ratios of $\mathrm{CD} 8^{+} \mathrm{T}$ cells to $\mathrm{T}_{\text {regs }}$ correlated with worse outcomes in patients with serous ovarian cancer. ${ }^{47}$ In comparison with rhIL-2, dosing of ALKS 4230 in mice results in increased NK cell and memory $\mathrm{CD}^{+} \mathrm{T}$ cell expansion without $\mathrm{T}_{\mathrm{reg}}$ expansion, resulting in greater effector cell to $\mathrm{T}_{\text {reg }}$ ratios. The ability to drive greater responses by NK cells, as evidenced by the expansion of $\mathrm{CD}^{2} 1 \mathrm{~b}^{+} \mathrm{CD} 27 \mathrm{NK}$ cells in mice or the higher frequency of CD25 and CD69 expression in human NK cells, may translate to greater antitumor responses. In addition, ALKS 4230 drove the expansion of greater numbers of $\mathrm{CD} 8^{+} \mathrm{T}$ cells but did not induce the expression of PD-1, LAG-3, and TIM-3 proteins, markers that have been associated with $\mathrm{CD}^{+} \mathrm{T}$ cell exhaustion. ${ }^{38}{ }^{39}$ In support of the relevance of these differences, ALKS 4230 treatment resulted in greater antitumor efficacy than rhIL-2 in the mouse B16F10 lung colonization model. Thus, the activation and expansion of effector cells without expansion of $\mathrm{T}_{\text {regs }}$ in response to ALKS 4230 correlates with improved efficacy relative to rhIL-2, which expands both effector lymphocytes and $\mathrm{T}_{\text {regs }}$ in concert. In addition to the desirable cellular responses elicited by ALKS 4230, the profile of systemic proinflammatory cytokines produced on repeated administration of ALKS 4230 is distinct, with rhIL-2 treatment inducing markedly higher levels of cytokines typically associated with cytokine release syndrome, including IL-6, TNF $\alpha$, and IFN $\gamma^{48}$ Levels of other proinflammatory cytokines such as IL-5, which is associated with eosinophilia induced by highdose IL-2, ${ }^{49}$ were also lower in response to ALKS 4230. 
These differences in systemic proinflammatory cytokine levels support the primary goals of enhancing efficacy while improving tolerability.

In addition to its selectivity profile, ALKS 4230 has several distinctive properties that contribute to its potential as an immunotherapeutic. In ALKS 4230, circular permutation allows the IL-2 portion to retain its native three-dimensional structure while enabling direct fusion to IL-2R $\alpha$ with a short linker. ALKS 4230 adopts the same structure as the native complex of IL-2 and IL-2R $\alpha$ (figure 1D) through the use of glycine-serine linkers, which are widely used in therapeutic protein engineering. ${ }^{50}$ IL-2R $\alpha$ is a natural binding partner of IL-2, and thus the binding interface between circularly permuted IL-2 and IL-2R $\alpha$ becomes part of the hydrophobic core of the resulting globular protein, ALKS 4230. This contributes to the stability and homogeneity of the molecule in solution, as compared with aldesleukin, which when resuspended is a large molecular weight microaggregate. The homogeneity of ALKS 4230 is confirmed by its migration as a monomer by size exclusion chromatography (Additional File 3: online supplementary figure S1).

ALKS 4230 is expressed in eukaryotic cells and is $\mathrm{N}$-glycosylated at two asparagine residues (Asn187 and Asn206), which also contributes to the improved biophysical properties of ALKS 4230 and increased molecular weight. After dosing in mice, the larger molecular weight of ALKS 4230 results in decreased clearance and translates to a longer half-life compared with rhIL-2, enabling less frequent dosing. In contrast, the circulating concentration of rhIL-2 rapidly falls below the level required to sufficiently activate $\mathrm{CD} 8^{+} \mathrm{T}$ cells and NK cells, but remains above the threshold for activation of $\mathrm{T}_{\text {regs }}$ for an extended period. These data indicate that the selectivity profile and favorable pharmacokinetics of ALKS 4230 facilitate a dosing paradigm that achieves NK and $\mathrm{CD}^{+} \mathrm{T}$ cell activation without undesired $\mathrm{T}_{\text {reg }}$ activation. ALKS 4230 administered IV and SC drove equivalent antitumor efficacy in the B16F10 tumor model when given at doses predicted to achieve similar exposure. Furthermore, efficacy in response to ALKS 4230 treatment was equivalent when comparing once-weekly dosing with daily administration in the B16F10 melanoma lung tumor colonization model. This demonstrates that ALKS 4230 can be delivered by either IV or SC administration and with less frequent dosing, while achieving equivalent efficacy. Taken together, ALKS 4230 is a novel immunotherapeutic agent engineered to harness the immune-stimulating activities of rhIL-2 and improve its tolerability, while limiting its immuno-regulatory role of promoting $\mathrm{T}_{\text {reg }}$ function.

\section{CONCLUSIONS}

ALKS 4230 is an IL-2 fusion protein that is engineered to be unable to bind to the high-affinity IL-2R while retaining the ability to bind to the intermediate-affinity IL-2R. Although ALKS 4230 can induce modest activation of $\mathrm{T}_{\text {regs }}$ in vitro, it does not induce significant $\mathrm{T}_{\text {reg }}$ activation or expansion in vivo. By virtue of its design, ALKS 4230 potently activates NK cells and MP CD8 ${ }^{+} \mathrm{T}$ cells in vivo and exhibits greater antitumor efficacy in mice compared with rhIL-2. The combination of selective lymphocyte expansion, along with its improved pharmacokinetic profile, makes ALKS 4230 a compelling immunotherapeutic for evaluation as a monotherapy or in combination with other anticancer therapies including immune checkpoint inhibitors. Thus, ALKS 4230 is being investigated clinically in patients with advanced cancers (NCT02799095, NCT03861793, and NCT04144517).

Acknowledgements The authors thank Tamar Aprahamian, PhD, of JetPub Scientific Communications for providing medical writing and editorial support for the preparation of this manuscript, which was funded by Alkermes, Waltham, Massachusetts, in accordance with Good Publication Practice (GPP3) guidelines. The authors thank Ray Winquist for insightful discussion and review of the manuscript. The authors thank Leslie McSweeney, Andrew Majdoch and Raj Vijay for support with mammalian expression and purification of ALKS 4230. The authors also thank Julian Chen of University of Toledo for X-ray crystallography support. Lastly, the authors thank Emily Rosentrater for experimental support on human PBMC signaling assays, and Yanchun Zhao, Hong Ma, and Su-Ping Pearson for support with PK sample analyzes.

Contributors Designing of research studies: HCL, JEL, JLF, HLF, CW, LS, JCA; Conducting experiments: HCL, JEL, JLF, HLF, CW; Data analysis: HCL, JEL, JLF, HLF, CW, LS, MSE, JCA; Writing the manuscript: HCL, JEL, JCA. All authors read and approved the final manuscript.

Funding These studies were funded by Alkermes, Waltham, Massachusetts.

Competing interests HCL, JEL, HLF, CW, and LS are current employees of Alkermes, Inc. JCA is a former of employee of Alkermes. HCL, JEL, HLF, CW, LS, and JCA hold stock in Alkermes, Inc. Research performed at The Geisel School of Medicine at Dartmouth by JLF in the laboratory of MSE was funded by Alkermes, Inc.

\section{Patient consent for publication Not required.}

Ethics approval All mice used in these studies were housed, managed and cared for in accordance with the Guide for the Care and Use of Laboratory Animals (National Research Council, 2011).

Provenance and peer review Not commissioned; externally peer reviewed.

Data availability statement Data are available upon reasonable request. The data sets used and/or analyzed during the current study are available from the corresponding author upon reasonable request.

Open access This is an open access article distributed in accordance with the Creative Commons Attribution Non Commercial (CC BY-NC 4.0) license, which permits others to distribute, remix, adapt, build upon this work non-commercially, and license their derivative works on different terms, provided the original work is properly cited, appropriate credit is given, any changes made indicated, and the use is non-commercial. See http://creativecommons.org/licenses/by-nc/4.0/.

\section{REFERENCES}

1 Rotte A, Bhandaru M, Zhou Y, et al. Immunotherapy of melanoma: present options and future promises. Cancer Metastasis Rev 2015;34:115-28.

2 Fyfe G, Fisher RI, Rosenberg SA, et al. Results of treatment of 255 patients with metastatic renal cell carcinoma who received high-dose recombinant interleukin-2 therapy. J Clin Oncol 1995;13:688-96.

3 Brayer J, Fishman M. Regression of metastatic clear cell kidney cancer with interleukin-2 treatment following nivolumab (anti-PD-1) treatment. J Immunother 2014;37:187-91.

4 Clement JM, McDermott DF. The high-dose aldesleukin (IL-2) "select" trial: a trial designed to prospectively validate predictive models of response to high-dose IL-2 treatment in patients with metastatic renal cell carcinoma. Clin Genitourin Cancer 2009;7:E7-9.

5 Shanafelt AB, Lin Y, Shanafelt MC, et al. A T-cell-selective interleukin 2 mutein exhibits potent antitumor activity and is well tolerated in vivo. Nat Biotechnol 2000;18:1197-202. 
6 Phan GQ, Attia P, Steinberg SM, et al. Factors associated with response to high-dose interleukin-2 in patients with metastatic melanoma. J Clin Oncol 2001;19:3477-82.

7 Payne $\mathrm{R}$, Glenn L, Hoen $\mathrm{H}$, et al. Durable responses and reversible toxicity of high-dose interleukin-2 treatment of melanoma and rena cancer in a community hospital biotherapy program. $J$ Immunother Cancer 2014;2:13.

8 McDermott DF, Regan MM, Clark Jl, et al. Randomized phase III trial of high-dose interleukin-2 versus subcutaneous interleukin-2 and interferon in patients with metastatic renal cell carcinoma. $J$ Clin Oncol 2005;23:133-41.

9 McDermott DF, Atkins MB. Application of IL-2 and other cytokines in renal cancer. Expert Opin Biol Ther 2004;4:455-68.

10 Boyman O, Surh CD, Sprent J. Potential use of IL-2/anti-IL-2 antibody immune complexes for the treatment of cancer and autoimmune disease. Expert Opin Biol Ther 2006;6:1323-31.

11 Epstein AL, Mizokami MM, Li J, et al. Identification of a protein fragment of interleukin 2 responsible for vasopermeability. $J$ Nat/ Cancer Inst 2003;95:741-9.

12 Nakagawa K, Miller FN, Sims DE, et al. Mechanisms of interleukin-2induced hepatic toxicity. Cancer Res 1996;56:507-10.

13 Rochman Y, Spolski R, Leonard WJ. New insights into the regulation of T cells by gamma(c) family cytokines. Nat Rev Immunol 2009;9:480-90.

14 Smith KA. Interleukin-2: inception, impact, and implications. Science 1988;240:1169-76.

15 Waldmann TA. The biology of interleukin-2 and interleukin-15: implications for cancer therapy and vaccine design. Nat Rev Immunol 2006;6:595-601.

16 Malek TR, Bayer AL. Tolerance, not immunity, crucially depends on IL-2. Nat Rev Immunol 2004;4:665-74.

17 Antony PA, Restifo NP. Cd4+Cd25+ T regulatory cells, immunotherapy of cancer, and interleukin-2. J Immunother 2005;28:120-8.

18 Sitrin J, Ring A, Garcia KC, et al. Regulatory T cells control NK cells in an insulitic lesion by depriving them of IL-2. J Exp Med 2013:210:1153-65.

19 Sim GC, Martin-Orozco N, Jin L, et al. II-2 therapy promotes suppressive ICOS+ Treg expansion in melanoma patients. J Clin Invest 2014:124:99-110.

20 Ross SH, Cantrell DA. Signaling and function of interleukin-2 in T lymphocytes. Annu Rev Immunol 2018;36:411-33.

21 Sim GC, Radvanyi L. The IL-2 cytokine family in cancer immunotherapy. Cytokine Growth Factor Rev 2014;25:377-90.

22 Huh D, Leslie DC, Matthews BD, et al. A human disease model of drug Toxicity-Induced pulmonary edema in a Lung-on-a-Chip Microdevice. Sci Transl Med 2012;4:ra147.

23 Krieg C, Létourneau S, Pantaleo G, et al. Improved IL-2 immunotherapy by selective stimulation of IL-2 receptors on lymphocytes and endothelial cells. Proc Natl Acad Sci U S A 2010;107:11906-11.

24 Charych DH, Hoch U, Langowski JL, et al. NKTR-214, an engineered cytokine with biased IL2 receptor binding, increased tumor exposure, and marked efficacy in mouse tumor models. Clin Cancer Res 2016;22:680-90.

25 Levin AM, Bates DL, Ring AM, et al. Exploiting a natural conformational switch to engineer an interleukin-2 'superkine'. Nature 2012;484:529-33.

26 Carmenate T, Pacios A, Enamorado M, et al. Human IL-2 mutein with higher antitumor efficacy than wild type IL-2. J Immunol 2013;190:6230-8.

27 Ward NC, Yu A, Moro A, et al. IL-2/CD25: a long-acting fusion protein that promotes immune tolerance by selectively targeting the IL-2 receptor on regulatory T cells. J Immunol 2018;201:2579-92.

28 Wang X, Rickert M, Garcia KC. Structure of the quaternary complex of interleukin-2 with its alpha, beta, and gammac receptors. Science 2005;310:1159-63.
29 Puskas J, Skrombolas D, Sedlacek A, et al. Development of an attenuated interleukin-2 fusion protein that can be activated by tumour-expressed proteases. Immunology 2011;133:206-20.

30 Pillet A-H, Lavergne V, Pasquier V, et al. II-2 induces conformational changes in its preassembled receptor core, which then migrates in lipid raft and binds to the cytoskeleton meshwork. J Mol Biol 2010:403:671-92.

31 Gong JH, Maki G, Klingemann HG. Characterization of a human cell line (NK-92) with phenotypical and functional characteristics of activated natural killer cells. Leukemia 1994;8:652-8.

32 Starkebaum G, Loughran TP, Waters CA, et al. Establishment of an IL-2 independent, human T-cell line possessing only the P70 IL-2 receptor. Int J Cancer 1991;49:246-53.

33 Poli A, Michel T, Thérésine M, et al. CD56bright natural killer (NK) cells: an important NK cell subset. Immunology 2009;126:458-65.

34 Létourneau S, Krieg C, Pantaleo G, et al. IL-2- and CD25-dependent immunoregulatory mechanisms in the homeostasis of T-cell subsets. J Allergy Clin Immunol 2009;123:758-62.

35 Baras AS, Drake C, Liu J-J, et al. The ratio of CD8 to Treg tumorinfiltrating lymphocytes is associated with response to cisplatinbased neoadjuvant chemotherapy in patients with muscle invasive urothelial carcinoma of the bladder. Oncoimmunology 2016;5:e1134412.

36 Faget J, Sisirak V, Blay J-Y, et al. ICOS is associated with poor prognosis in breast cancer as it promotes the amplification of immunosuppressive $\mathrm{CD} 4^{+} \mathrm{T}$ cells by plasmacytoid dendritic cells. Oncoimmunology 2013;2:e23185

37 Kornete M, Sgouroudis E, Piccirillo CA. ICOS-dependent homeostasis and function of Foxp3+ regulatory T cells in islets of nonobese diabetic mice. J Immunol 2012;188:1064-74.

38 Jin H-T, Anderson AC, Tan WG, et al. Cooperation of Tim-3 and PD-1 in CD8 T-cell exhaustion during chronic viral infection. Proc Natl Acad Sci U S A 2010;107:14733-8.

39 Blackburn $\mathrm{SD}$, Shin $\mathrm{H}$, Haining WN, et al. Coregulation of CD8+ T cell exhaustion by multiple inhibitory receptors during chronic viral infection. Nat Immunol 2009;10:29-37.

40 Fu B, Wang F, Sun R, et al. Cd11B and CD27 reflect distinct population and functional specialization in human natural killer cells. Immunology 2011;133:350-9.

41 Vossen MTM, Matmati M, Hertoghs KML, et al. Cd27 defines phenotypically and functionally different human NK cell subsets. $J$ Immunol 2008;180:3739-45.

42 Hartemann A, Bensimon G, Payan CA, et al. Low-Dose interleukin 2 in patients with type 1 diabetes: a phase $1 / 2$ randomised, double-blind, placebo-controlled trial. Lancet Diabetes Endocrinol 2013;1:295-305.

43 Mizui M, Tsokos GC. Low-Dose IL-2 in the treatment of lupus. Curr Rheumatol Rep 2016;18:68.

44 Koreth J, Ritz J, Tsokos GC, et al. Low-Dose interleukin-2 in the treatment of autoimmune disease. Oncol Hematol Rev 2014;10:157.

45 Gasteiger G, Hemmers S, Firth MA, et al. II-2-Dependent tuning of NK cell sensitivity for target cells is controlled by regulatory T cells. $J$ Exp Med 2013;210:1167-78.

46 Damjanovich S, Bene L, Matkó J, et al. Preassembly of interleukin 2 (IL-2) receptor subunits on resting kit $225 \mathrm{~K} 6 \mathrm{~T}$ cells and their modulation by IL-2, IL-7, and IL-15: a fluorescence resonance energy transfer study. Proc Natl Acad Sci U S A 1997;94:13134-9.

47 Preston CC, Maurer MJ, Oberg AL, et al. The ratios of CD8+ T cells to CD4+CD25+ Foxp3+ and FOXP3- T cells correlate with poor clinical outcome in human serous ovarian cancer. PLoS One 2013;8:e80063.

48 Lee DW, Gardner R, Porter DL, et al. Current concepts in the diagnosis and management of cytokine release syndrome. Blood 2014:124:188-95.

49 van Haelst Pisani C, Kovach JS, Kita H, et al. Administration of interleukin-2 (IL-2) results in increased plasma concentrations of IL-5 and eosinophilia in patients with cancer. Blood 1991;78:1538-44.

50 Chen X, Zaro JL, Shen W-C. Fusion protein linkers: property, design and functionality. Adv Drug Deliv Rev 2013;65:1357-69. 